Article

\title{
Spatial Distribution of Polyphenolic Compounds in Corn Grains (Zea mays L. var. Pioneer) Studied by Laser Confocal Microscopy and High-Resolution Mass Spectrometry
}

\author{
Mayya Razgonova ${ }^{1,2, * \mathbb{D}}$, Yulia Zinchenko ${ }^{2} \mathbb{D}$, Konstantin Pikula ${ }^{3,4}{ }^{\mathbb{D}}$, Lyudmila Tekutyeva ${ }^{1}$, Oksana Son ${ }^{1}$, \\ Alexander Zakharenko ${ }^{5,6}{ }^{(D)}$, Tatiana Kalenik ${ }^{1}$ and Kirill Golokhvast ${ }^{3,5,7}$ (D)
}

check for updates

Citation: Razgonova, M.; Zinchenko, Y.; Pikula, K.; Tekutyeva, L.; Son, O.; Zakharenko, A.; Kalenik, T.; Golokhvast, K. Spatial Distribution of Polyphenolic Compounds in Corn Grains (Zea mays L. var. Pioneer) Studied by Laser Confocal Microscopy and High-Resolution Mass Spectrometry. Plants 2022, 11, 630. https://doi.org/10.3390/ plants11050630

Academic Editors:

Raymond Wightman and Bertrand Dubreucq

Received: 10 November 2021

Accepted: 23 February 2022

Published: 25 February 2022

Publisher's Note: MDPI stays neutral with regard to jurisdictional claims in published maps and institutional affiliations.

Copyright: (C) 2022 by the authors. Licensee MDPI, Basel, Switzerland. This article is an open access article distributed under the terms and conditions of the Creative Commons Attribution (CC BY) license (https:/ / creativecommons.org/licenses/by/ $4.0 /)$.
1 Institute of Life Science and Biomedicine, Far Eastern Federal University, 10 Ajax Bay, Russky Island, 690922 Vladivostok, Russia; lat7777@mail.ru (L.T.); oksana_son@bk.ru (O.S.); kalenik.tk@dvfu.ru (T.K.)

2 N.I. Vavilov All-Russian Institute of Plant Genetic Resources, B. Morskaya 42-44, 190000 Saint Petersburg, Russia; yu-zinch@yandex.ru

3 Polytechnical Institute, Far Eastern Federal University, 10 Ajax Bay, Russky Island, 690922 Vladivostok, Russia; pikula_ks@dvfu.ru (K.P.); golokhvast@sfsca.ru (K.G.)

4 Federal Research Center the Yakut Scientific Center of the Siberian Branch of the Russian Academy of Sciences, 2, Petrovskogo Str., 677000 Yakutsk, Russia

5 Siberian Federal Scientific Centre of Agrobiotechnology, Centralnaya, Presidium, 633501 Krasnoobsk, Russia; rarf@yandex.ru

6 Laboratory of Supercritical Fluid Research and Application in Agrobiotechnology, The National Research Tomsk State University, 36, Lenin Avenue, 634050 Tomsk, Russia

7 Pacific Geographical Institute, Far Eastern Branch of the Russian Academy of Sciences, Radio 7, 690041 Vladivostok, Russia

* Correspondence: razgonova.mp@dvfu.ru

Abstract: Desirable changes in the biochemical composition of food plants is a key outcome of breeding strategies. The subsequent localization of nutritional phytochemicals in plant tissues gives important information regarding the extent of their synthesis across a tissue. We performed a detailed metabolomic analysis of phytochemical substances of grains from Zea mays L. (var. Pioneer) by tandem mass spectrometry and localization by confocal microscopy. We found that anthocyanins are located mainly in the aleurone layer of the grain. High-performance liquid chromatography in combination with ion trap tandem mass spectrometry revealed the presence of 56 compounds, including 30 polyphenols. This method allows for effective and rapid analysis of anthocyanins by plotting their distribution in seeds and grains of different plants. This approach will permit a more efficient screening of phenotypic varieties during food plant breeding.

Keywords: confocal microscopy; HPLC-MS/MS; tandem mass spectrometry; polyphenolic compounds

\section{Introduction}

The consumption of corn for 2018-2019 reached 315 million tons in the USA, 276 million tons in China, 63 million tons in the European Union, and 66 million tons in Brazil. In maize breeding, the discovery of genes responsible for the formation of corn endosperm accelerated research on the modeling of nutritional and taste properties of the corn.

The biochemical composition of corn grains, including protein, fatty acid, saccharide, and phenolic content, significantly affect the nutritional quality and taste of corn. The content of essential amino acids, such as valine, isoleucine, leucine, lysine, methionine, threonine, tryptophan, phenylalanine, histidine, and arginine is one of the major factors that determine the nutritional value of corn [1].

Corn grains have the highest polyphenol content $(6056.9 \mathrm{mg} / \mathrm{kg}$ dry weight or $15.55 \mu \mathrm{mol} / \mathrm{g}$ ) among other grains and represent significant interest for phytochemical and metabolomic study [2,3]. Phenolic compounds can have radical scavenging, chelating and 
antioxidative activity. Polyphenols can prevent oxidative stress caused by metabolic imbalances between the production and scavenging of free radicals [4]. Phenolic compounds can control oxidative stress by neutralizing or reducing the formation of reactive oxygen species (ROS) or restoration of redox homeostasis by strengthening the endogenous defense system or capturing the ROS [5]. The ability of polyphenolic groups to scavenge free radicals is associated with their aromatic rings and a highly conjugated system with many hydroxyl groups. The spatial position and the number of hydroxyl groups are important reference points for the antioxidant activity of phenolic compounds [6].

Fatty acids affect the palatability and especially the odor of foods. In higher plants, the proportion of essential fatty acids in the composition of vegetable fats is very high (up to $90 \%$ ). It is mainly composed of palmitic, oleic, and linoleic acids. Analysis of the fatty acid composition of corn grains showed the presence of palmitic acid, linoleic acid, vaccenic acid, oleic acid, stearic acid, and eicosanoic acid.

Monosaccharides are derivatives of polyhydric alcohols and serve as a source for the synthesis of disaccharides (sucrose, maltose, lactose), oligosaccharides, and polysaccharides (cellulose and starch). Many of them have a sweet taste, but there are gradations from tasteless to bitter substances that affect the taste qualities of grains, including corn.

Flavonoids act as exogenous antioxidants and are directly oxidized by radicals with the formation of less reactive species through the following mechanisms: inhibition of xanthine oxidase activity, modulation of channel pathways, and inhibition of nitric oxide synthase activity [7]. The antioxidant potential of flavonoids is associated with the location and the total number of $\mathrm{OH}$ groups, or rather, with their molecular structure [8]. The use of flavonoids in biological systems holds great promise for bone tissue engineering. Quercetin, an antioxidant flavonoid, when present in the bloodstream, improves vascular health and reduces the risk of cardiovascular disease in its conjugated form. Quercetin and its derivatives prevent blood clotting or thrombosis and prevent the likelihood of stroke [9].

The structure of corn grain is presented in Figure 1 [10].

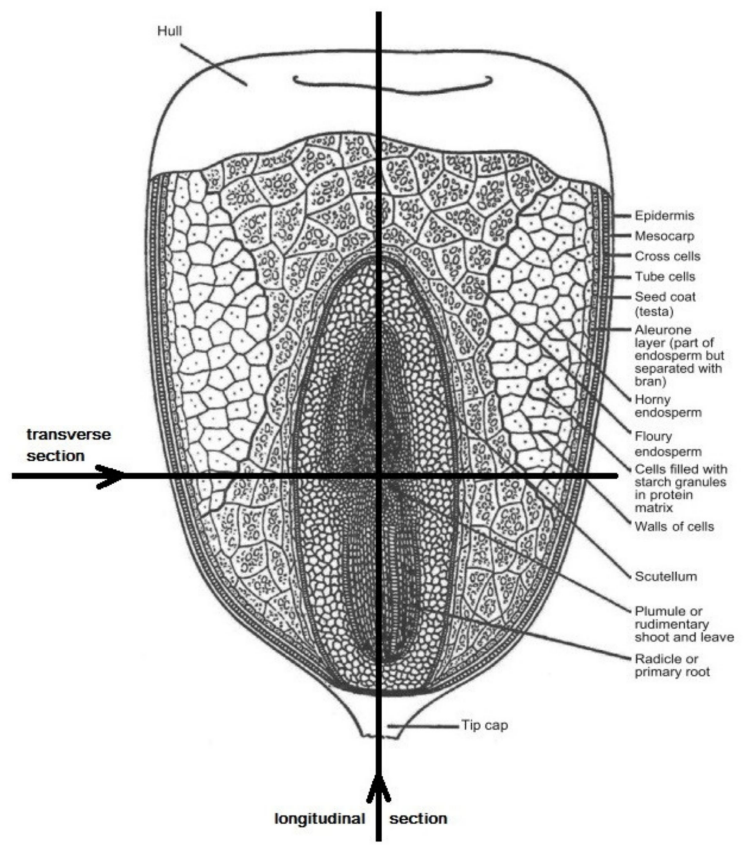

Figure 1. Structure of the grain of dent corn (with the symbolic designation of parts of the grain) (modified from [10]).

Previous research organized phenolic compounds according to the degree of antioxidant activity: simple phenolic acids < hydroxycinnamic acids < flavonols < flavan-3-ols $<$ dimers of procyanidins [6]. It is known that the antioxidant activity of phenolic acids increases with an increase in the distance separating the carbonyl group and the aromatic 
ring, and hydroxycinnamic acid derivatives have stronger antioxidant activity than benzoic acid derivatives [11]. The 7,8-double bond of hydroxycinnamic acids also enhances their antioxidant potential, compared with hydroxybenzoic acids.

Jigh-performance liquid chromatography (HPLC) was predominantly used to identify carotenoids [12-14] and polyphenols [15,16] in corn grains. A review by Ranilla (2020) summarized the application of metabolomics for the characterization of metabolites in corn grains and emphasized the importance of phenotype-genotype studies aimed to explore corn genetic diversity [17]. The application of electrospray ionization mass spectrometry (ESI-MS) in combination with HPLC is a cost-effective and statistically robust method for high-throughput phenotypic characterization of corn [18]. The HPLC-ESI-MS/MS analytical configuration is widely used for the characterization of phenolic bioactive compounds in worldwide corn biodiversity. Montilla et al. (2011) characterized 10 corn landraces based on the content of phenolic fractions [19]. Das and Singh (2016) characterized four corn hybrids based on the content of phenolic acids, anthocyanins, and flavonols [20].

Another important problem is the study of spatial distribution and composition of phytochemicals in corn grains. Microscopic images are widely used as important sources of information on morphometric characteristics of cells and the architecture of plant tissue [21]. Confocal laser scanning microscopy was previously used to localize the phenolic compounds in different plants [22]. Morphological and biochemical changes in roots of corn Zea mays L. were previously studied by confocal microscopy [23,24]. To the best of the authors' knowledge, no published studies report an application of confocal microscopy for the identification of phytochemicals in the grains of corn Zea mays L.

Considering the qualitative data of phytochemical composition obtained by HPLCMS and literature information regarding the optical properties of identified chemicals, the combination of HPLC data with fluorescence microscopy is a good opportunity to explore the localization of phenolic compounds in plants. The combination of these methods is important for breeding since it allows us to assess whether the genes involved in the synthesis of these substances are expressed only in certain tissues (e.g., the aleurone layer, the germ layer, the vitreous endosperm) or in all grain glutes uniformly. In addition, this approach makes it possible to estimate the number and size of storing organelles (granules, chloroplasts, vesicles), since selection is important in both increasing their number and increasing their size. Thus, the combination of these methods allows us to obtain more complex information about the studied plants.

In this study, we used combined mass spectrometry and confocal laser microscopy to determine the structural properties and phytochemical composition of corn grains. In our case, the combination of HPLC-MS and fluorescence microscopy allowed us to demonstrate the localization of polyphenolic compounds in the grains of corn Zea mays L. However, the interpretation of the results of this study requires taking into account the limitations of the study design. The application of combined HPLC and fluorescent microscopy includes the possibility of spatial localization of different groups of plant chemicals in general but not the individual compounds.

\section{Results}

\subsection{Tandem Mass Spectrometry}

The extracts of corn grains were analyzed using liquid chromatography-electrospray ionization mass spectrometry (LC-ESI MS) to explore the diversity of available phytochemicals. The structural identification of each compound was carried out based on their accurate mass and MS/MS fragmentation using LC-ESI MS. In total, 56 compounds were successfully identified and characterized by comparing fragmentation patterns with those available in the literature. The results of a preliminary study showed the presence of 56 compounds corresponding to the genus Zea, some of which were identified for the first time in Zea mays L. The identified compounds, with molecular formulas $m / z$ calculated and observed MS/MS data, and their comparative profile for corn grains are summarized 
in Table A1. The chromatograms of total compounds in the grain extract in positive and negative ionization modes are presented in Figure 2.

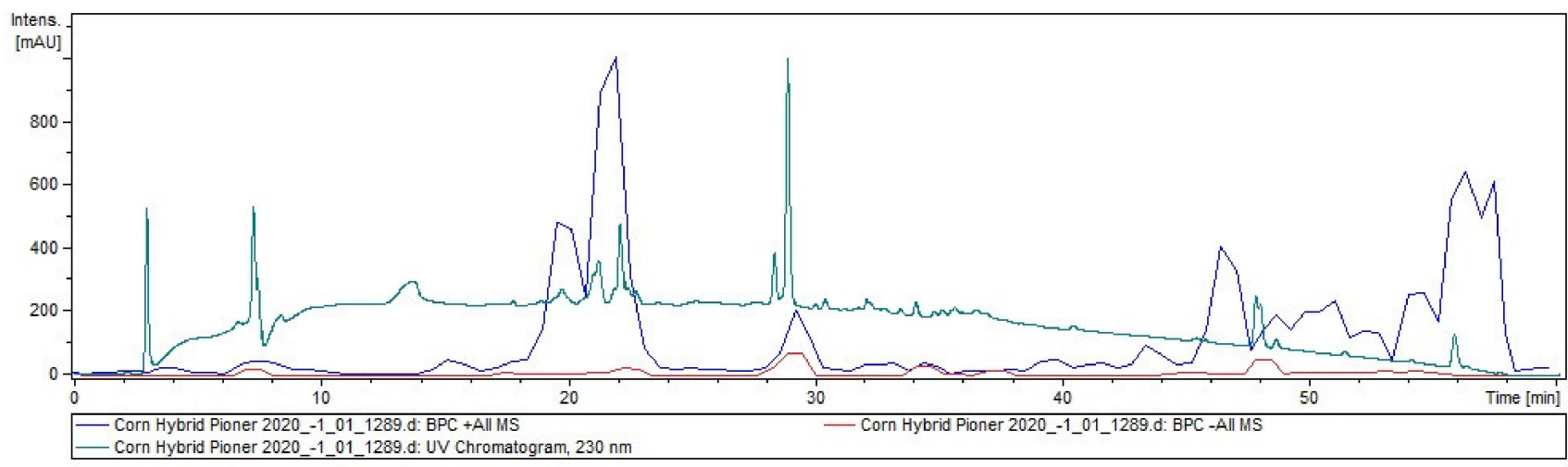

Figure 2. The total compounds chromatogram of Zea mays L. (var. Pioneer) extract.

In the present study, 30 polyphenol compounds were identified and characterized. In addition, 26 compounds of other classes were identified, including identified for the first time in corn grains oxylipins 13-trihydroxy-octadecenoic acid and 9,12,13-Trihydroxy-trans10-octadecenoic acid.

Figures 3 and 4 show examples of the decoding spectra (collision-induced dissociation (CID) spectrum) of the ion chromatogram obtained using tandem mass spectrometry. The $[\mathrm{M}-\mathrm{H}]^{-}$ion produced three fragment ions at $m / z 171, m / z 211$, and $m / z 293$ (Figure 3). The fragment ion at $m / z 171$ yields a daughter ion at $m / z$ 153. This compound was identified in the bibliography as 13-trihydroxy-octadecenoic acid (THODE) in extracts from Bituminaria [25], Broccoli [26], Sasa veitchii [27].

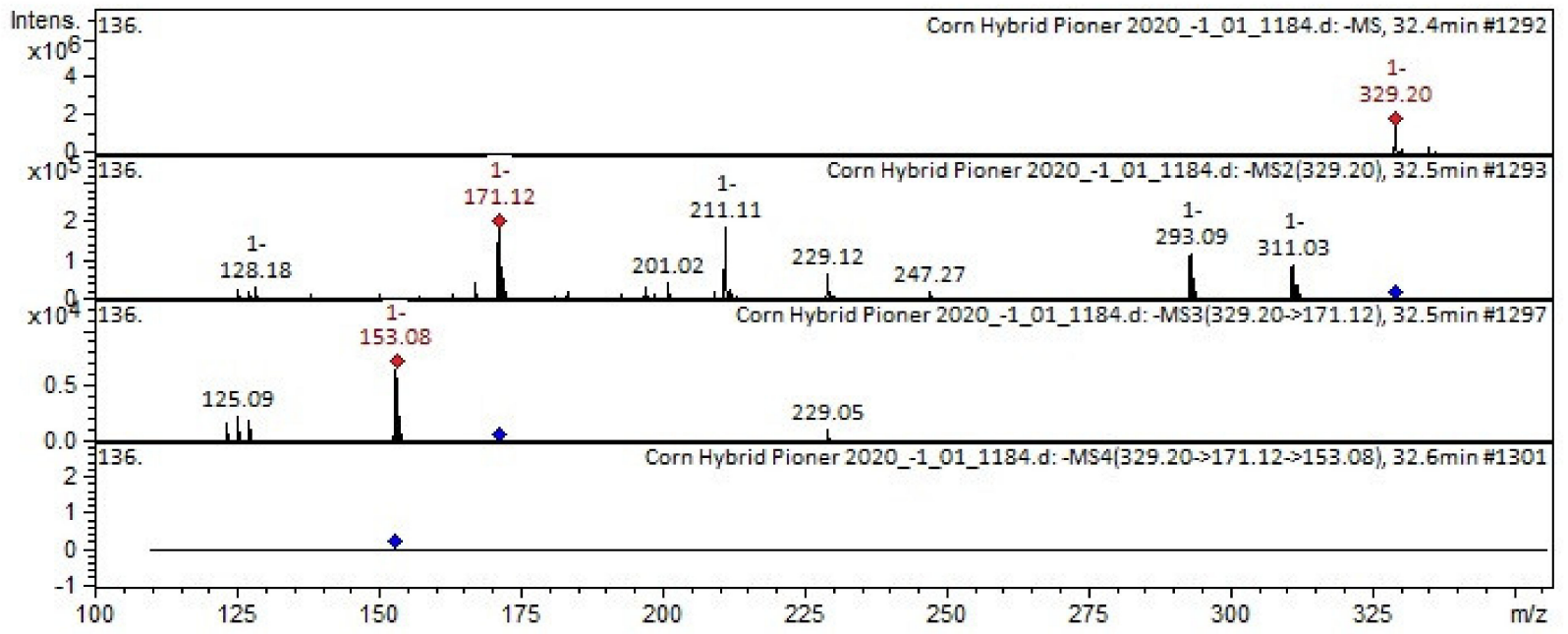

Figure 3. Mass spectrum of 13-trihydroxy-octadecenoic acid (THODE) from the extract of corn grains, $m / z 329.20$.

The mass spectrum in the positive ion mode of pelargonidin-3-o-glucoside from extracts of corn grains is shown in Figure 4 . The $[\mathrm{M}+\mathrm{H}]^{+}$ion produced three fragment ions at $m / z 271, m / z 415$, and $m / z 186$ (Figure 4). The fragment ion at $m / z 271$ yields two daughter ions at $m / z 253$ and $m / z 121$. The fragment ion at $m / z 253$ yields one daughter ion at $m / z$ 235. To our knowledge, pelargonidin-3-o-glucoside was reported in Triticum aestivum L. [28,29], strawberry [30]. 


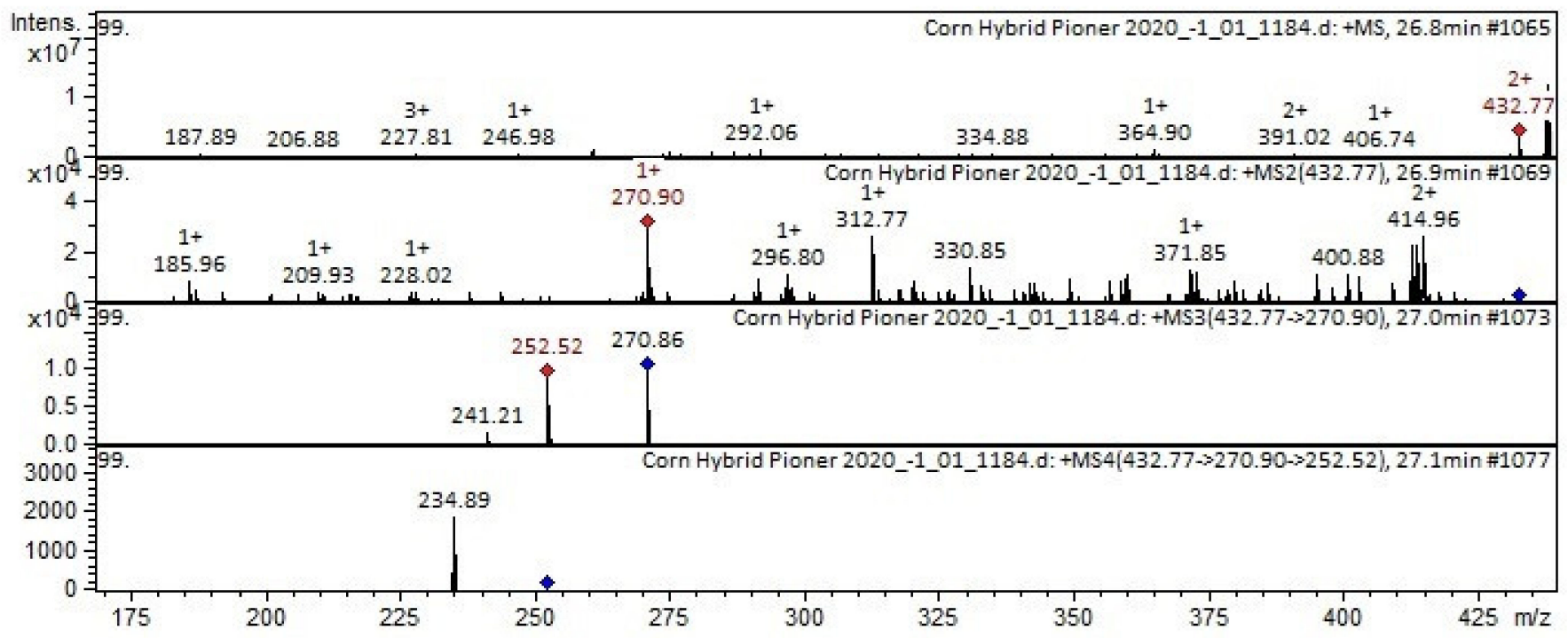

Figure 4. Mass spectrum of pelargonidin-3-O-glucoside from extracts of corn grains, $m / z 432.77$.

\subsection{Confocal Microscopy}

Confocal microscopy, coupled with Airyscan technology, demonstrated blue (Figures 5b, 6b and 7b) and red fluorescence (Figures 5c, 6c and 7c) in the longitudinal and transverse sections, and in the aleurone layer of the grain, respectively.

According to the literature data, strong blue fluorescence of plant grains under UV excitation could be explained by the presence of phenolic compounds such as hydroxycinnamic [31] or ferulic acid [32], and lignin [33]. The endosperm reveals very low blue autofluorescence (Figures 6 and 7) due to the very low amount of phenolic substances in the endosperm cells of seeds and grains [34]. It was reported that the pericarp of Zea mays had a total phenolic content 30-34 fold higher than endosperm [35]. Our results demonstrated that the aleurone cells (Figures 5b, 6b and 7b) and embryo (Figure 7b) were enriched with blue autofluorescence substances. At the same time, it is known that no lignin is present in aleurone [36], but hydroxycinnamic, ferulic, and coumaric acids were reported in aleurone cells of cereals $[37,38]$. Therefore, the observed blue fluorescence might be caused by hydroxycinnamic, ferulic, and coumaric acids. The main blue fluorescent compound in the pericarp is lignin, which is a heterogeneous mixture of randomly polymerized phenolic monolignols [39].

The emission in the red spectrum mainly occurs due to the presence of various polyphenolic compounds, including anthocyanins and anthocyanidins [40]. 


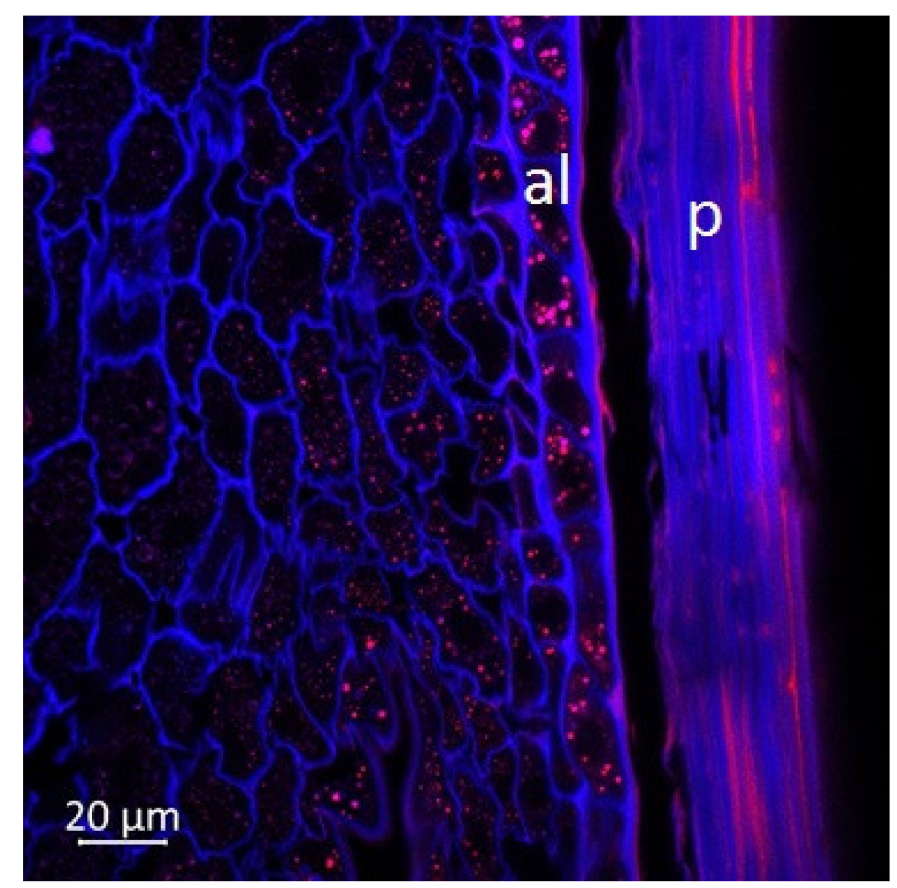

(a)

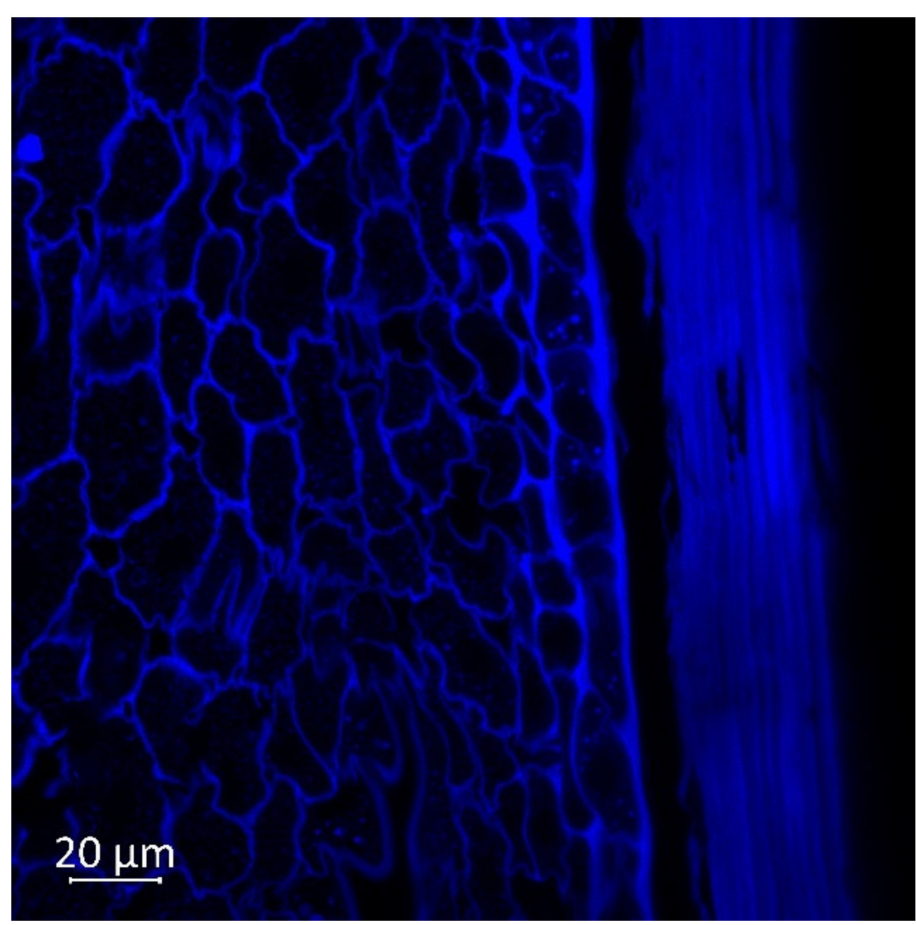

(b)

Figure 5. Cont. 


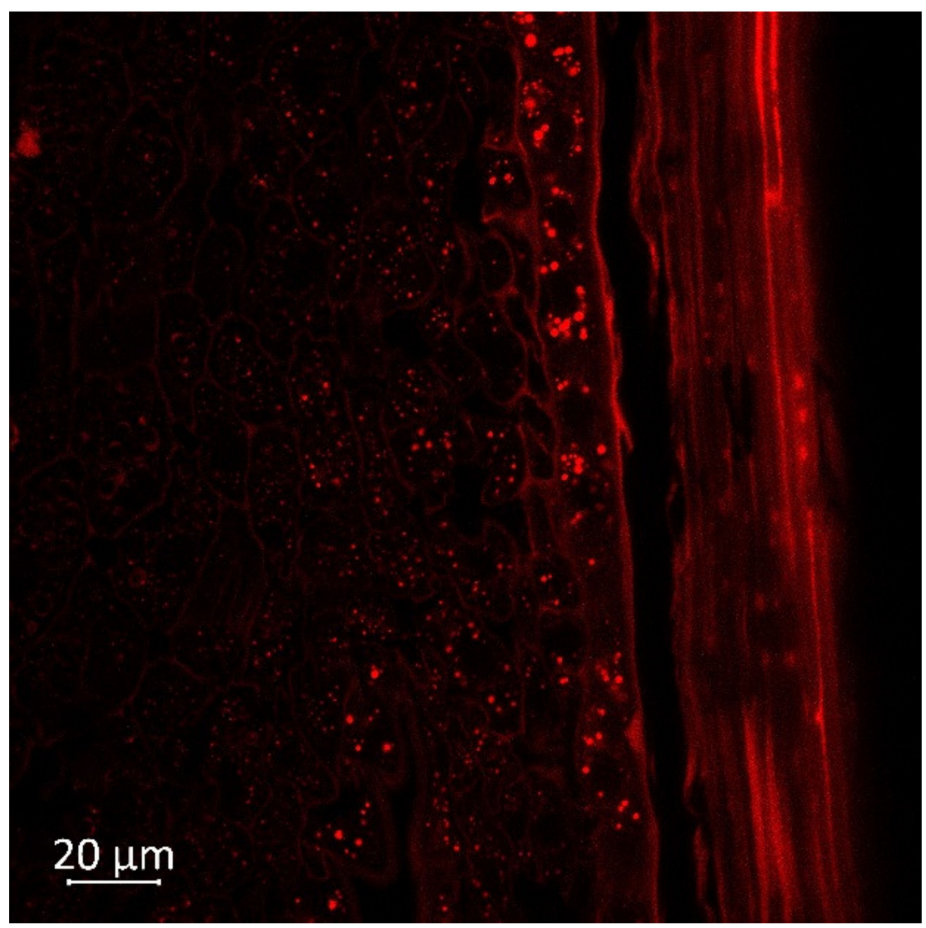

(c)

Figure 5. The longitudinal section of the grain (grain margin in the embryo area), $63 \times$ magnification: (a) multispectral image, excitation $405 \mathrm{~nm}$ with the emission in 400-470 nm (blue), excitation $488 \mathrm{~nm}$ with the emission in 620-700 nm (red); (b) hydroxycinnamic and ferulic acids, and lignin content in the corn grain indicated in blue spectra; (c) anthocyanin content in the grain indicated in red spectra; p, pericarp; al, aleurone.

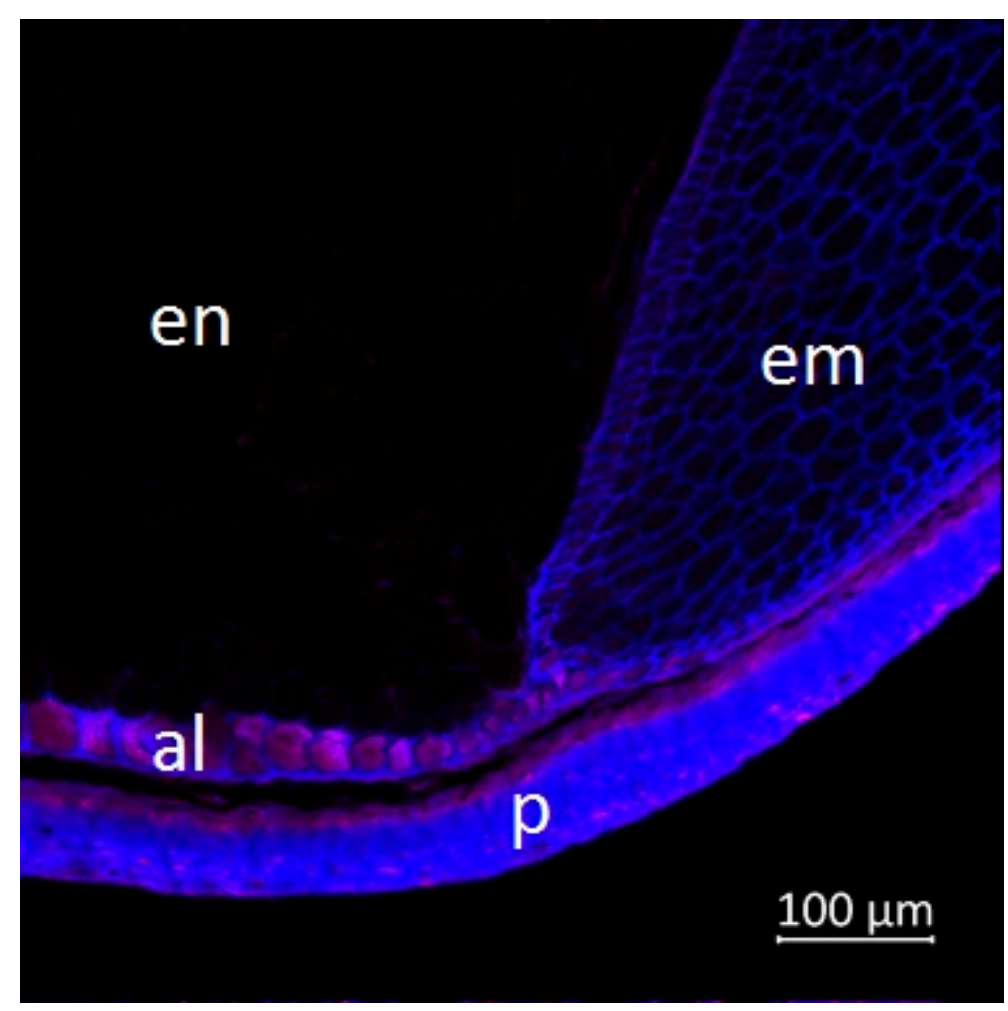

(a)

Figure 6. Cont. 


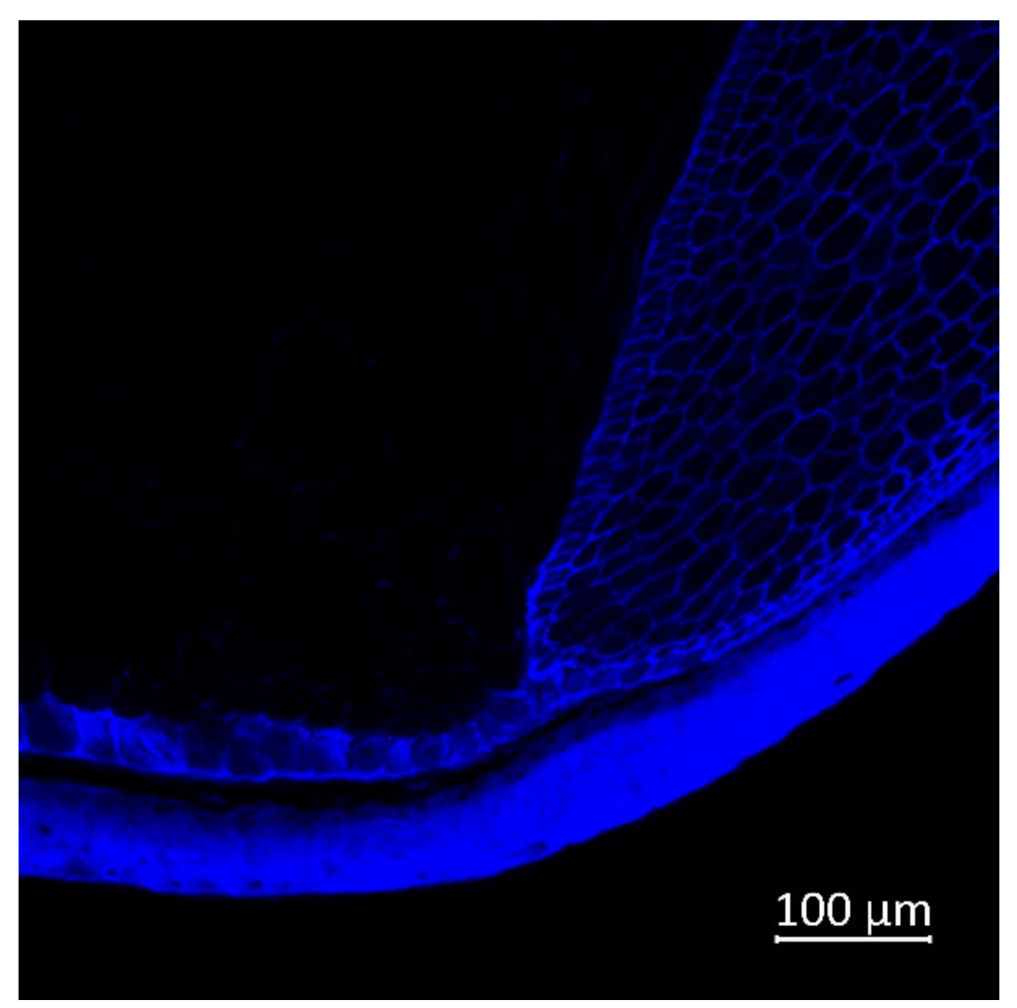

(b)

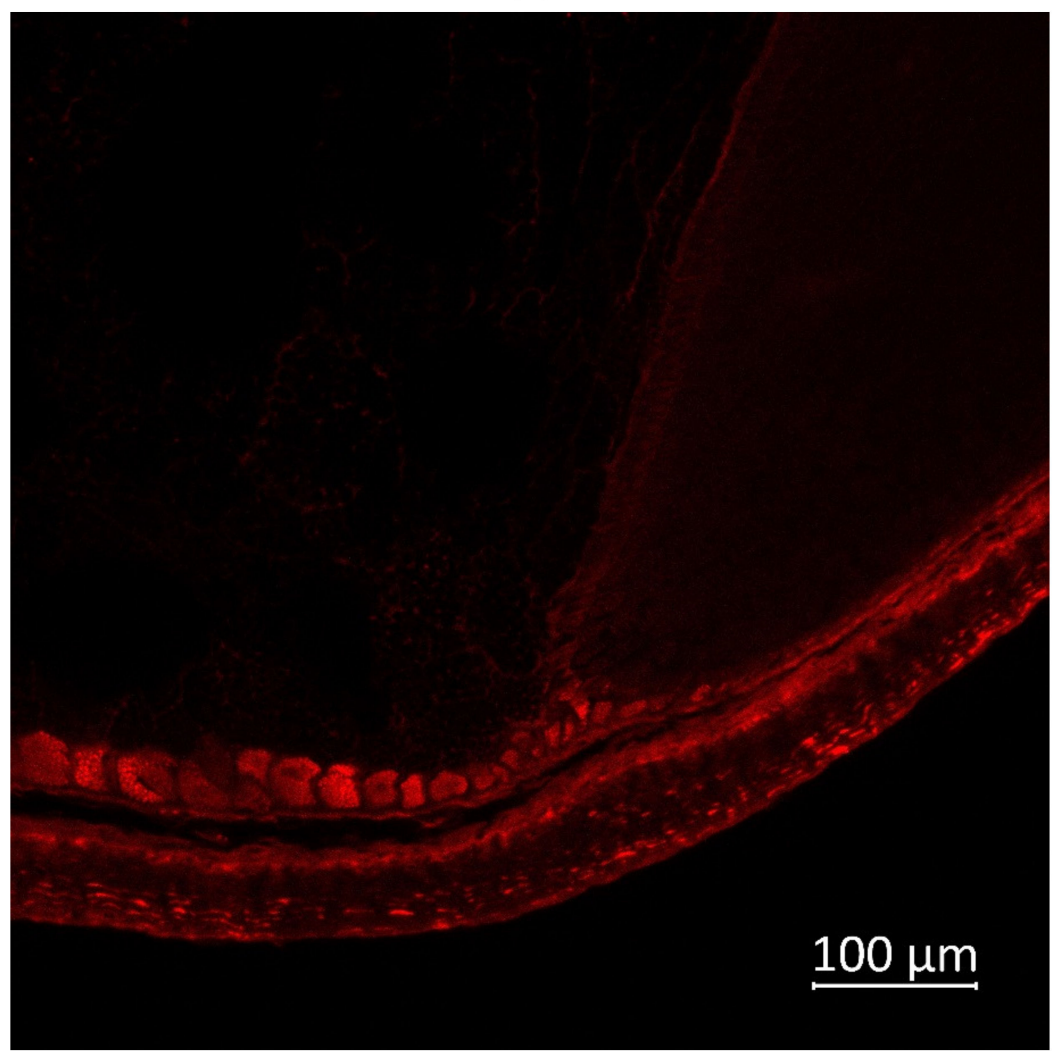

(c)

Figure 6. The transverse section of the grain, a border between endosperm (left) and embryo (right), $20 \times$ magnification: (a) multispectral image, excitation $405 \mathrm{~nm}$ with the emission in $400-470 \mathrm{~nm}$ (blue), excitation $488 \mathrm{~nm}$ with the emission in 620-700 nm (red); (b) hydroxycinnamic and ferulic acids, and lignin content in the corn grain indicated in blue spectra; (c) anthocyanin content in the grain indicated in red spectra; $\mathrm{p}$, pericarp; al, aleurone; en, endosperm; em, embryo. 


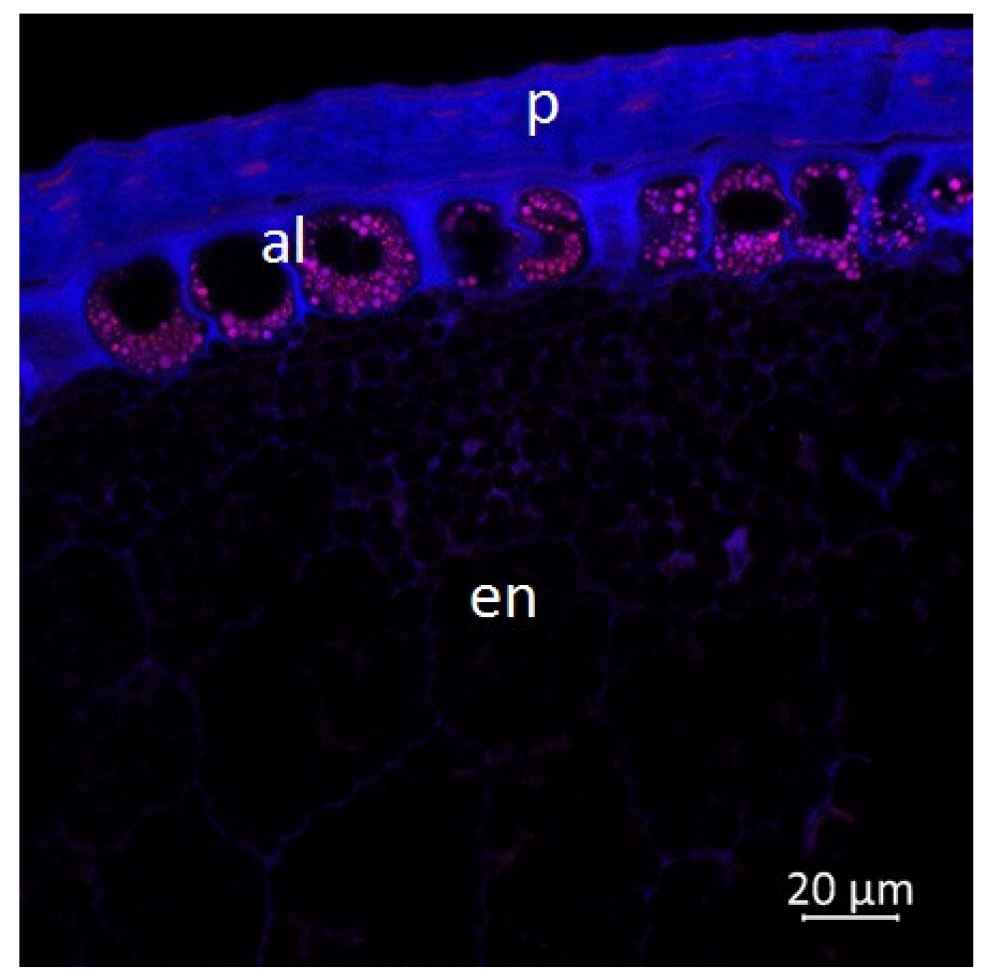

(a)

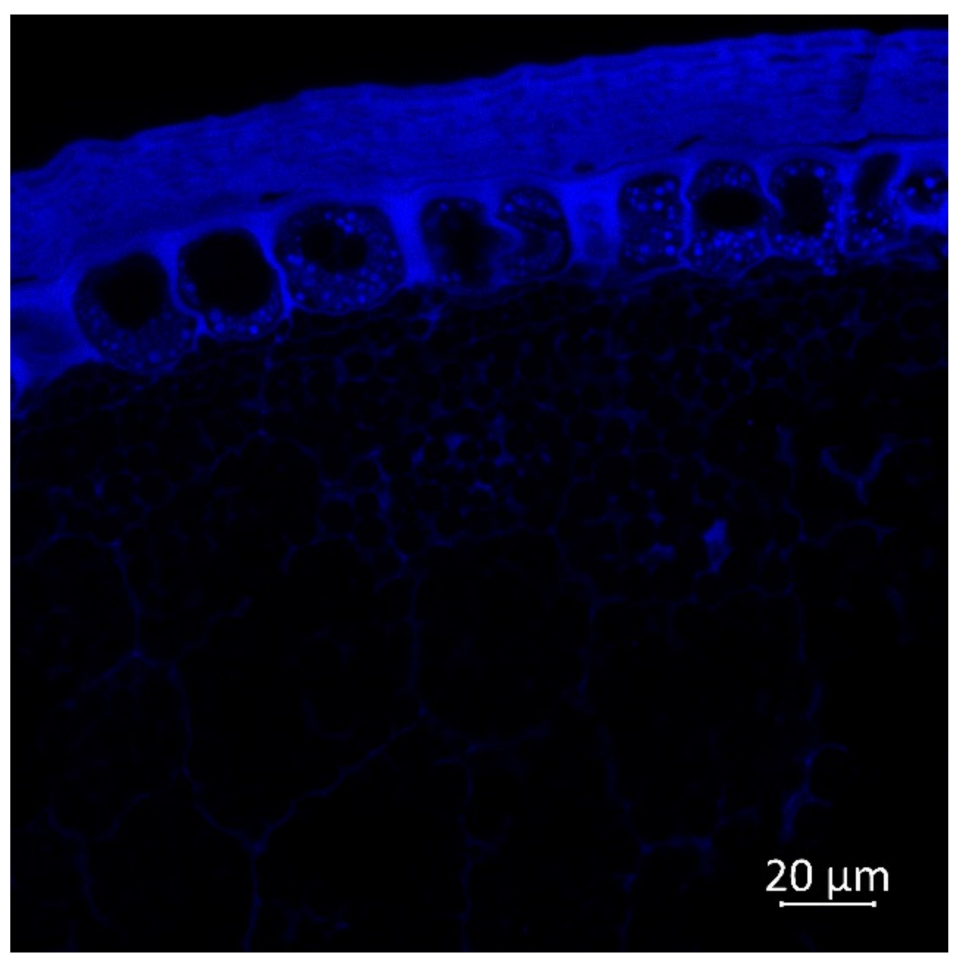

(b)

Figure 7. Cont. 


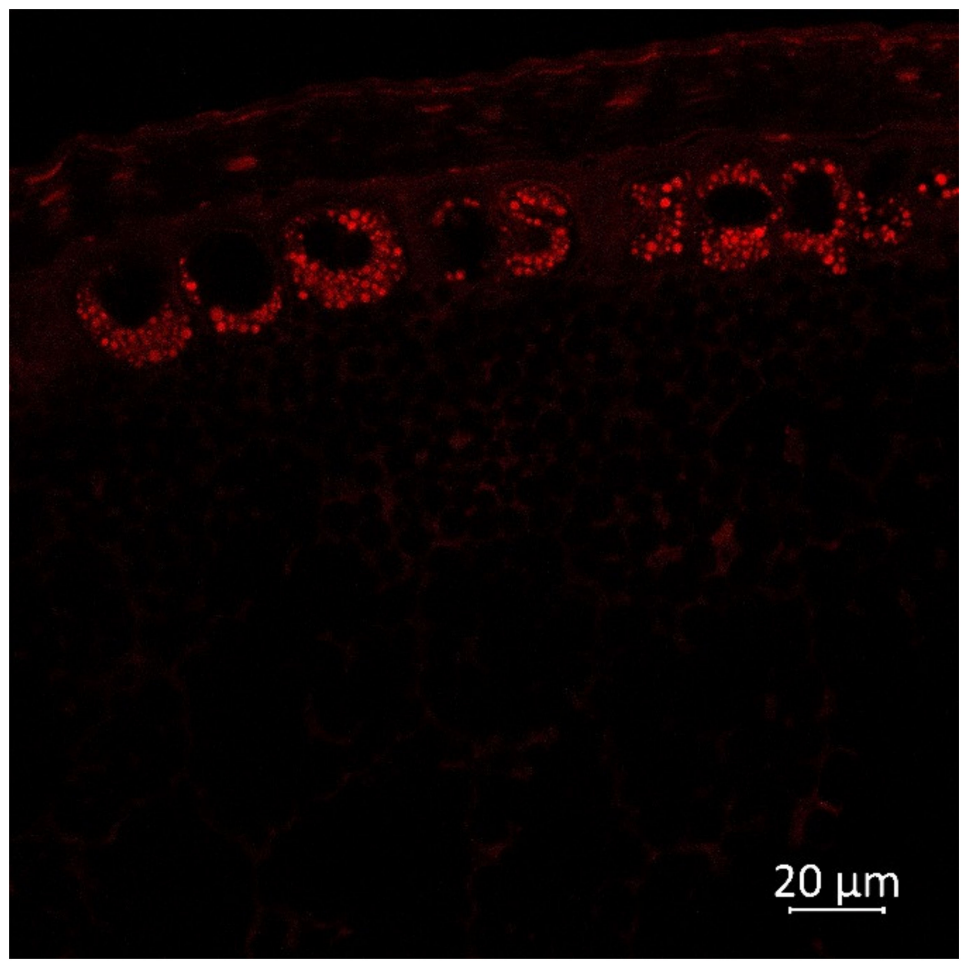

(c)

Figure 7. The aleurone layer of the grain (upper margin of the grain, the longitudinal section), $63 \times$ magnification: (a) multispectral image, excitation $405 \mathrm{~nm}$ with the emission in 400-470 nm (blue), excitation $488 \mathrm{~nm}$ with the emission in 620-700 nm (red); (b) hydroxycinnamic and ferulic acids, and lignin content in the corn grain indicated in blue spectra; (c) anthocyanin content in the grain indicated in red spectra; $p$, pericarp; al, aleurone; en, endosperm.

\section{Discussion}

It is known that polyphenols have strong antioxidation, anticancer, anti-infection, and other valuable activities [41]. The knowledge of polyphenol distribution in plants will benefit the development of the methods of their direct extraction and further application in the food, pharmaceutical, and cosmetic industries.

Another important problem is the influence of environmental conditions on the polyphenol composition of the plants. The significant genotypic effects and interactions of the genotype with the environment suggest that breeding methodology will require careful site selection and accounting for changes in genotype rank with changes in cultivation sites.

The important characteristics such as grain color, protein, and polyphenol distribution represent significant interest for breeding. In the grain images, the fluorescence signal under UV excitation ( $405 \mathrm{~nm}$ ) comes from ferulic acid [42] and lignin [33]. It should be noted that lignin is absent in aleurone, while coumaric and diferulic acids are present in the walls of aleurone cells. These acids can contribute to the autofluorescence of these cell walls $[43,44]$.

Autofluorescence in the aleurone cell walls was not uniform, which is consistent with the studies presented below. Saadi et al. (1998) showed that autofluorescence was more intense in the anticline than in the periclinal cell walls of the corn grains [45]. Moreover, studies have shown that the content of ferulic acid in the anticlinal cell wall of the corn was twice as high as in the periclinal cell wall [46]. However, research by Phillippe et al. [34] argues that anticlinal and periclinal cell walls contain equal amounts of feruloylated arabinoxylan. Therefore, it seems that autofluorescence in the walls of anticlinal aleurone cells can additionally be caused by other substances, for example, coumaric and diferulic acids, which were found in aleurone cells [37]. 
Our study showed the metabolic profile of the corn Zea mays L. (var. Pioneer) represented as 56 compounds including 2 compounds identified in corn grains for the first time-namely, oxylipins 13-trihydroxy-octadecenoic acid and 9,12,13-trihydroxy-trans-10octadecenoic acid. Laser microscopy showed the presence of polyphenolic compounds and, in particular, hydroxycinnamic and ferulic acids, and anthocyanins, in the tissues of corn grain.

The method used in this study is effective for rapid analysis of the distribution of polyphenolic compounds in seeds and grains of different plants. This approach allows the study of plant morphology and the characterization of relevant bioactive phytochemicals using an inexpensive and fast methodology. The characterization of novel corn hybrid genotypes harvested from different geographical areas is a strategic problem and addressing this problem would allow sustainable development of local agriculture.

\section{Materials and Methods}

\subsection{Materials and Chemicals}

As an object of research, we used corn grains Zea mays L., variety Pioneer P1467. The sample was harvested in 2020 in urban-type settlement Kirovsky (Primorsky Krai, Russian Far East) and obtained from a local farmer.

HPLC-grade acetonitrile was purchased from Fisher Scientific (Southborough, UK), MS-grade formic acid was from Sigma-Aldrich (Steinheim, Germany). Ultra-pure water was prepared from SIEMENS ULTRA clear (SIEMENS Water Technologies, Munich, Germany), and all other chemicals were analytical grade.

\subsection{Fractional Maceration}

Fractional maceration technique was applied to obtain highly concentrated extracts [47]. From $500 \mathrm{~g}$ of the sample, $4 \mathrm{~g}$ of corn seeds was randomly selected for maceration. The total amount of the extractant (ethyl alcohol of reagent grade) was divided into 3 parts, and the grains were consistently infused with the first, second, and third parts. The solid-solvent ratio was 1:20. The infusion of each part of the extractant lasted 7 days at room temperature.

\subsection{Liquid Chromatography}

HPLC was performed using Shimadzu LC-20 Prominence HPLC (Shimadzu, Kyoto, Japan) equipped with a UV sensor and C18 silica reverse phase column $(4.6 \times 150 \mathrm{~mm}$, particle size: $2.7 \mu \mathrm{m}$ ) to perform the separation of multicomponent mixtures. The gradient elution program with two mobile phases (A, deionized water; $\mathrm{B}$, acetonitrile with formic acid $0.1 \% v / v$ ) was as follows: $0-2 \mathrm{~min}, 0 \% \mathrm{~B} ; 2-50 \mathrm{~min}, 0-100 \% \mathrm{~B}$; control washing 50-60 min 100\% B. The entire HPLC analysis was performed with a UV-vis detector SPD20A (Shimadzu, Kyoto, Japan) at a wavelength of $230 \mathrm{~nm}$ for identification of catechin, epicatechin, quercetin, and other compounds [48]; the temperature was $50{ }^{\circ} \mathrm{C}$, and the

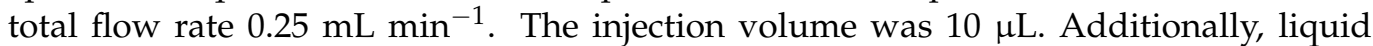
chromatography was combined with a mass spectrometric ion trap to identify compounds.

\subsection{Mass Spectrometry}

MS analysis was performed on an ion trap amaZon SL (Bruker Daltoniks, Bremen, Germany) equipped with an ESI source in negative ion mode. The optimized parameters were obtained as follows: ionization source temperature: $70{ }^{\circ} \mathrm{C}$, gas flow: $9 \mathrm{~L} / \mathrm{min}$, nebulizer gas (atomizer): 7.3 psi, capillary voltage: $4500 \mathrm{~V}$, endplate bend voltage: $1500 \mathrm{~V}$, fragmentary: $280 \mathrm{~V}$, collision energy: $60 \mathrm{eV}$. An ion trap was used in the scan range $\mathrm{m} / \mathrm{z}$ 100-1.700 for MS and MS/MS. All experiments were repeated three times. A four-stage ion separation mode (MS/MS mode) was implemented.

\subsection{Optical Microscopy}

Before the microscopic examination, a longitudinal and transverse dissection of corn grains was performed with MS-2 sled microtome (Tochmedpribor, Ukraine). The obtained 
sliced corn grains were placed on microscopic cover glass through immersion oil to reduce light refraction by air gaps.

The autofluorescence parameters of a slice of corn grain were determined using an inverted confocal microscope (confocal laser scanning microscopy-CLSM, LSM 800, Carl Zeiss Microscopy GmbH, Berlin, Germany). The autofluorescence spectrum was chosen using lambda scan mode of the confocal microscope, which allows to determine the emission maximum in a specific sample and obtain spectral acquisition. The specimen was excited by each laser separately and two main peaks of autofluorescence were revealed: excitation by a UV laser, $405 \mathrm{~nm}$ (solid state, diode, $5 \mathrm{~mW}$ ) with the emission maxima in the ranges $400-470 \mathrm{~nm}$ (blue); excitation by a blue laser, $488 \mathrm{~nm}$ (solid state, diode, $10 \mathrm{~mW}$ ) with the emission maximum in 620-700 $\mathrm{nm}$ (red). The used power and detector gain for blue and red channels were $5 \%$ and $750 \mathrm{~V}$, and $7 \%$ and $850 \mathrm{~V}$, respectively.

The images were obtained using objectives Plan-Apochromat $20 \times / 0.8$ M27 and PlanApochromat $63 \times / 1.40$ Oil DIC M27 with $20 \times$ and $63 \times$ magnification, correspondingly. The zoom factor was 0.5. Airyscan at the SR mode was used to increase resolution. The software ZEN 2.1 (Carl Zeiss Microscopy GmbH, Berlin, Germany) was used for image acquisition.

\section{Conclusions}

We determined the qualitative characteristics of secondary metabolites in the tissues of corn Zea mays L. (var. Pioneer). In total, 56 compounds were identified, including 2 compounds identified in corn grains for the first time-namely, oxylipins 13-trihydroxyoctadecenoic acid and 9,12,13-trihydroxy-trans-10-octadecenoic acid.

The combination of these data with fluorescence microscopy data revealed the most probable localization of phenolic and polyphenolic compounds. In addition, confocal microscopy allowed us to assess the localization of hydroxycinnamic and ferulic acids in aleurone cells and embryos and anthocyanin content in pericarp and aleurone cells. The combination of these methods is important for breeding since it allows us to assess whether the genes involved in the synthesis of these substances are expressed only in certain tissues (the aleurone layer, the germ layer, the vitreous endosperm) or in all grain glutes uniformly. In addition, this approach makes it possible to estimate the number and size of storing organelles (granules, chloroplasts, vesicles), since selection is important both in the area of increasing their number and increasing their size. Thus, the combination of these methods allows us to obtain more complete information about the variables under study. In addition, it shows that confocal microscopy can be used to obtain preliminary information during volumetric screenings of varietal samples, which will allow selecting target groups for more detailed analysis much faster and without the use of expensive reagents.

Author Contributions: Conceptualization, M.R.; methodology, M.R. and A.Z.; investigation, M.R., Y.Z. and K.P.; resources, L.T., O.S. and T.K.; writing—original draft preparation, M.R.; supervision, K.G.; project administration, L.T. and T.K.; funding acquisition, L.T. All authors have read and agreed to the published version of the manuscript.

Funding: This research was carried out with financial support of the Ministry of Education and Science of the Russian Federation within the framework of the implementation of a complex project for the creation of high-tech production provided by the Decree of the Russian Federation Government dated 9 April 2010 № 218. The project is entitled “Development of industrial technology and organization in the Far Eastern Federal District of the high-tech production of feed Vitamin A of increased stability and bioavailability", agreement № 075-11-2021-065, 25 June 2021.

Institutional Review Board Statement: Not applicable.

Informed Consent Statement: Not applicable.

Data Availability Statement: The data presented in the current study are available in the article.

Conflicts of Interest: The authors declare no conflict of interest. 


\section{Appendix A}

Table A1. The list of compounds identified in ethanolic extracts of Zea mays L. (var. Pioneer) grains.

\begin{tabular}{|c|c|c|c|c|c|c|c|c|c|c|}
\hline No. & Class & Compound & $\begin{array}{c}\text { Molecular } \\
\text { Formula }\end{array}$ & $\begin{array}{l}\text { Calculated } \\
\text { Mass }\end{array}$ & $\begin{array}{c}\text { Molecular Ion } \\
{[\mathrm{M}-\mathrm{H}]^{-}}\end{array}$ & $\begin{array}{c}\text { Molecular Ion } \\
{[\mathrm{M}+\mathrm{H}]^{+}}\end{array}$ & $\begin{array}{l}\text { Fragmenation } \\
\text { Ion MS2 }\end{array}$ & $\begin{array}{l}\text { Fragmentation } \\
\text { Ion MS3 }\end{array}$ & $\begin{array}{l}\text { Fragmentation } \\
\text { Ion MS4 }\end{array}$ & References \\
\hline \multicolumn{11}{|c|}{ POLYPHENOLS } \\
\hline 1 & Phenolic acid & $\begin{array}{c}\text { Caffeic acid } \\
\text { [(2E)-3-(3,4-Dihydroxyphenyl)acrylic acid] }\end{array}$ & $\mathrm{C}_{9} \mathrm{H}_{8} \mathrm{O}_{4}$ & 180.1574 & & 181 & 135 & 119 & & $\begin{array}{l}\text { Dracocephalum palmatum [49]; } \\
\text { Eucalyptus [50]; Triticum [51]; } \\
\text { Salvia miltiorrhiza [52] }\end{array}$ \\
\hline 2 & Phenolic acid & Hydroxy methoxy dimethylbenzoic acid & $\mathrm{C}_{10} \mathrm{H}_{12} \mathrm{O}_{4}$ & 196.1999 & & 197 & $177 ; 153$ & 125 & & F. herrerae; F. glaucescens [53] \\
\hline 3 & Phenolic acid & Hydroxyferulic acid & $\mathrm{C}_{10} \mathrm{H}_{10} \mathrm{O}_{5}$ & 210.1834 & & 211 & $193 ; 125$ & & & Andean blueberry [54]; \\
\hline 4 & Stilbene & $\begin{array}{l}\text { Resveratrol [trans-Resveratrol; } \\
\text { 3,4',5-Trihydroxystilbene; Stilbentriol] }\end{array}$ & $\mathrm{C}_{14} \mathrm{H}_{12} \mathrm{O}_{3}$ & 228.2433 & & 229 & 209 & 163 & 146 & $\begin{array}{l}\text { A. cordifolia; F. Flaucescens; F. } \\
\text { herrerae [53]; Radix polygoni } \\
\text { multiflori [55] }\end{array}$ \\
\hline 6 & Flavan-3-ol & Epiafzelechin [(epi)Afzelechin] & $\mathrm{C}_{15} \mathrm{H}_{14} \mathrm{O}_{5}$ & 274.2687 & & 275 & $245 ; 176$ & 175 & & $\begin{array}{c}\text { Cassia granidis [58]; } \\
\text { Cassia abbreviata [59,60]; } \\
\text { A. cordifolia; F. glaucescens; } F \text {. } \\
\text { herrerae [53] }\end{array}$ \\
\hline 7 & Flavonol & $\begin{array}{c}\text { Kaempferol [3,5,7-Trihydroxy-2-(4-hydro- } \\
\text { xyphenyl)-4H-chromen-4-one] }\end{array}$ & $\mathrm{C}_{15} \mathrm{H}_{10} \mathrm{O}_{6}$ & 286.2363 & 285 & & $185 ; 117 ; 257$ & 117 & & $\begin{array}{c}\text { Rhus coriaria (Sumac) [61]; } \\
\text { Lonicera japonicum [62]; } \\
\text { Andean blueberry [54]; Potato } \\
\text { [63]; } \\
\text { Potato leaves [56]; }\end{array}$ \\
\hline 8 & Flavan-3-ol & Catechin [D-Catechol] & $\mathrm{C}_{15} \mathrm{H}_{14} \mathrm{O}_{6}$ & 290.2681 & & 291 & $261 ; 189$ & $173 ; 242$ & $191 ; 143$ & $\begin{array}{c}\text { Potato [64]; Triticum [51]; } \\
\text { millet grains [65]; } \\
\text { Solanaceae [66]; Beer [67]; V. } \\
\text { edulis [53]; Vigna inguiculata } \\
\text { [68]; } \\
\text { Radix polygoni multiflori [55]; } \\
\text { Senna singueana [69]] Camellia } \\
\text { kucha [70]; }\end{array}$ \\
\hline 9 & Flavan-3-ol & (epi)catechin & $\mathrm{C}_{15} \mathrm{H}_{14} \mathrm{O}_{6}$ & 290.2681 & & 291 & $261 ; 173$ & $243 ; 173$ & & $\begin{array}{l}\text { C. edulis [53]; Radix polygoni } \\
\text { multiflori [55]; Camellia kucha } \\
\text { [70]; }\end{array}$ \\
\hline 10 & $\begin{array}{l}\text { Hydroxycinnamic } \\
\text { acid }\end{array}$ & Caffeoylmalic acid & $\mathrm{C}_{13} \mathrm{H}_{12} \mathrm{O}_{8}$ & 296.2296 & 295 & & $277 ; 171$ & $233 ; 113$ & & $\begin{array}{l}\text { Potato leaves [56]; } \\
\text { Strawberry [71] }\end{array}$ \\
\hline
\end{tabular}


Table A1. Cont.

\begin{tabular}{|c|c|c|c|c|c|c|c|c|c|c|}
\hline No. & Class & Compound & $\begin{array}{l}\text { Molecular } \\
\text { Formula }\end{array}$ & $\begin{array}{l}\text { Calculated } \\
\text { Mass }\end{array}$ & $\underset{[\mathbf{M}-\mathbf{H}]^{-}}{\text {Molecular Ion }}$ & $\begin{array}{c}\text { Molecular Ion } \\
{[\mathrm{M}+\mathrm{H}]^{+}}\end{array}$ & $\begin{array}{l}\text { Fragmenation } \\
\text { Ion MS2 }\end{array}$ & $\begin{array}{l}\text { Fragmentation } \\
\text { Ion MS3 }\end{array}$ & $\begin{array}{l}\text { Fragmentation } \\
\text { Ion MS4 }\end{array}$ & References \\
\hline 11 & Flavonol & Quercetin & $\mathrm{C}_{15} \mathrm{H}_{10} \mathrm{O}_{7}$ & 302.2357 & & 303 & $\begin{array}{l}275 ; 245 ; 203 ; \\
\quad 175\end{array}$ & 175 & & $\begin{array}{c}\text { Rhus coriaria [61]; } \\
\text { Potato leaves [56]; } \\
\text { Vigna sinensis [72]; } \\
\text { Impatiens glandulifera Royle } \\
\text { [73]; } \\
\text { Eucalyptus [50]; Triticum [51]; } \\
\text { millet grains [65]; } \\
\text { Tomato [74]; } \\
\text { Bougainvillea [75] }\end{array}$ \\
\hline 12 & Flavan-3-ol & Gallocatechin [+(-) Gallocatechin] & $\mathrm{C}_{15} \mathrm{H}_{14} \mathrm{O}_{7}$ & 306.2675 & & 307 & $277 ; 207$ & 207; 159 & & $\begin{array}{c}\text { millet grains [65]; } \\
\text { Solanaceae [66]; } \\
\text { Licania rididigna [76]; } \\
\text { G. linguiforme [53]; } \\
\text { Senna singueana [69]; } \\
\text { Vaccinium myrtillus [77] }\end{array}$ \\
\hline 13 & Flavonol & Myricetin & $\mathrm{C}_{15} \mathrm{H}_{10} \mathrm{O}_{8}$ & 318.2351 & & 319 & $291 ; 219 ; 174$ & $259 ; 191$ & $243 ; 161$ & $\begin{array}{c}\text { Dracocephalum palmatum [49] } \\
\text { Potato [63,64]; } \\
\text { Perilla frutescens [78]; } \\
\text { Tomato [74t]; } \\
\text { Mentha [79]; } \\
\text { Salvia miltiorrhiza [52]; } \\
\text { Rubus ocidentalis [80]; } \\
\text { Sanguisorba officinalis [81]; } \\
\text { Radix polygoni multiflori [55] }\end{array}$ \\
\hline 14 & Flavone & Cirsiliol & $\mathrm{C}_{17} \mathrm{H}_{14} \mathrm{O}_{7}$ & 330.2889 & 329 & & $229 ; 171 ; 293$ & $211 ; 155$ & 183 & Ocimum [82] \\
\hline 16 & Flavone & Luteolin 7,3'-disulphate & $\mathrm{C}_{15} \mathrm{H}_{10} \mathrm{O}_{12} \mathrm{~S}_{2}$ & 446.3627 & & 447 & 287 & 152 & & Zostera marina [84] \\
\hline 17 & Flavone & Apigenin 7-sulfate & $\mathrm{C}_{15} \mathrm{H}_{10} \mathrm{O}_{8} \mathrm{~S}$ & 350.3001 & & 351 & $337 ; 308$ & $308 ; 291$ & & $\begin{array}{l}\text { G. linguiforme [53]; } \\
\text { sulphates [85] }\end{array}$ \\
\hline 18 & Lignan & $\begin{array}{l}\text { Matairesinol [(-)-Matairesinol; Artigenin } \\
\text { Congener] }\end{array}$ & $\mathrm{C}_{20} \mathrm{H}_{22} \mathrm{O}_{6}$ & 358.3851 & & 359 & $324 ; 289 ; 127$ & 144 & 127 & $\begin{array}{l}\text { Punica granatum [86]; } \\
\text { Wheat [87]; } \\
\text { Lignans [88] }\end{array}$ \\
\hline 19 & $\begin{array}{l}\text { Hydroxycinnamic } \\
\text { acid derivative }\end{array}$ & Caffeic acid derivative & $\mathrm{C}_{16} \mathrm{H}_{18} \mathrm{O}_{9} \mathrm{Na}$ & 377.2985 & 377 & & $341 ; 215$ & $179 ; 113$ & & Bougainvillea [75] \\
\hline 20 & $\begin{array}{l}\text { Gallate ester, } \\
\text { derivative of } \\
\text { epiafzelechin }\end{array}$ & Epiafzelechin 3-O-gallate & $\mathrm{C}_{22} \mathrm{H}_{18} \mathrm{O}_{9}$ & 426.3729 & & 427 & $301 ; 171 ; 382$ & 171 & & Camellia kucha [70]; \\
\hline 21 & Flavone & Apigenin-C-hexoside & $\mathrm{C}_{21} \mathrm{H}_{20} \mathrm{O}_{10}$ & 432.3775 & & 433 & $\begin{array}{l}\text { 418; } 314 ; 265 ; \\
219 ; 155\end{array}$ & $257 ; 169$ & & $\begin{array}{l}\text { Triticum durum [89]; } \\
\text { Beer [67] }\end{array}$ \\
\hline 22 & Anthocyanidin & Pelargonidin-3-O-glucoside (callistephin) & $\mathrm{C}_{21} \mathrm{H}_{21} \mathrm{O}_{10}$ & 433.3854 & & 433 & $271 ; 185$ & $253 ; 121$ & 235 & $\begin{array}{l}\text { Triticum aestivum L. [28,29]; } \\
\text { strawberry [30] }\end{array}$ \\
\hline 23 & Anthocyanidin & $\begin{array}{l}\text { Cyanidin-3-O-glucoside [Cyanidin } \\
\text { 3-O-beta-D-Glucoside; Kuromarin] }\end{array}$ & $\mathrm{C}_{21} \mathrm{H}_{21} \mathrm{O}_{11}+$ & 449.3848 & 447 & & 285 & 199 & & $\begin{array}{c}\text { Triticum [29,51]; } \\
\text { acerola [90]; rice [91]; Vigna } \\
\text { sinensis [72]; Rapeseed petals } \\
\text { [92] }\end{array}$ \\
\hline
\end{tabular}


Table A1. Cont.

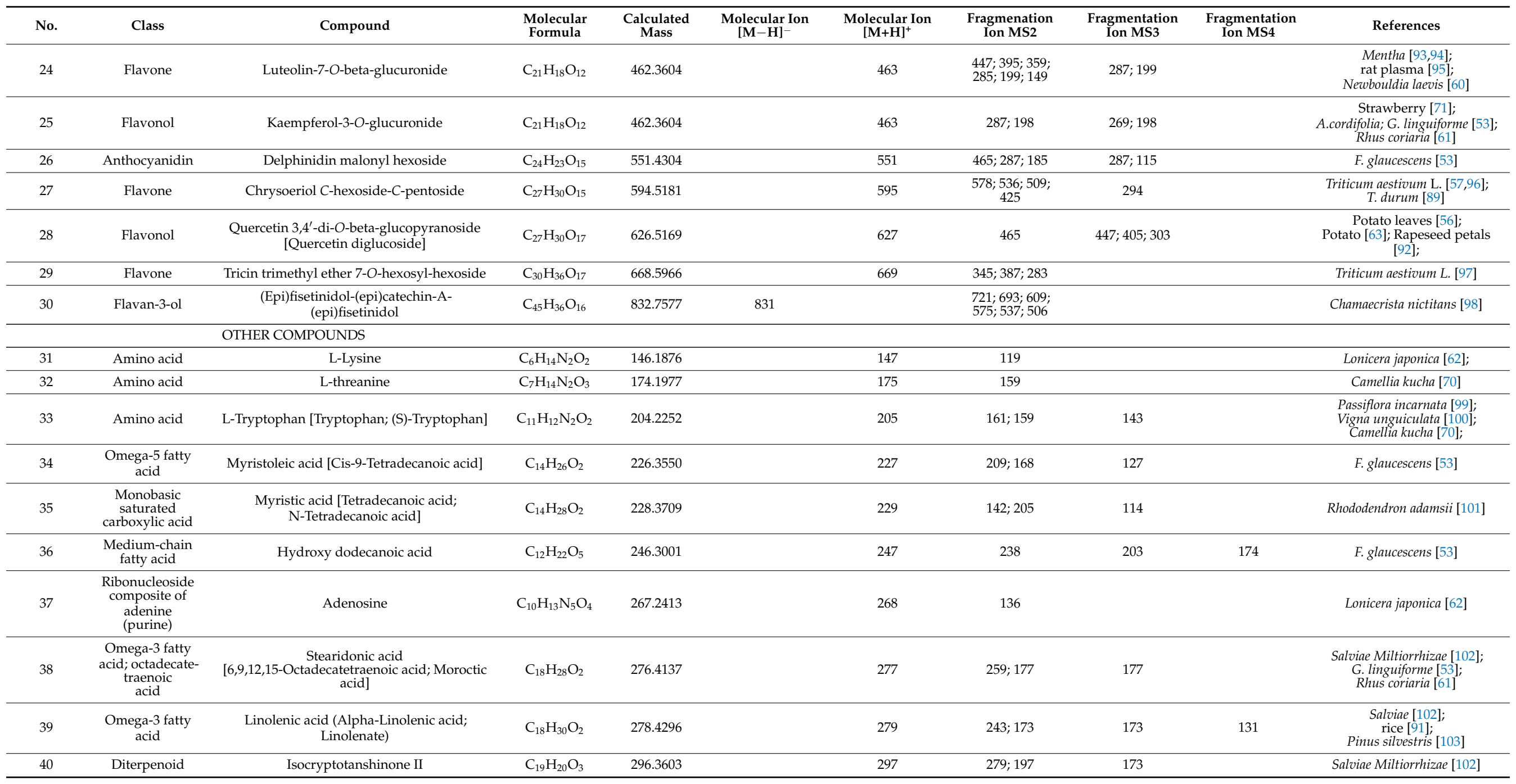


Table A1. Cont.

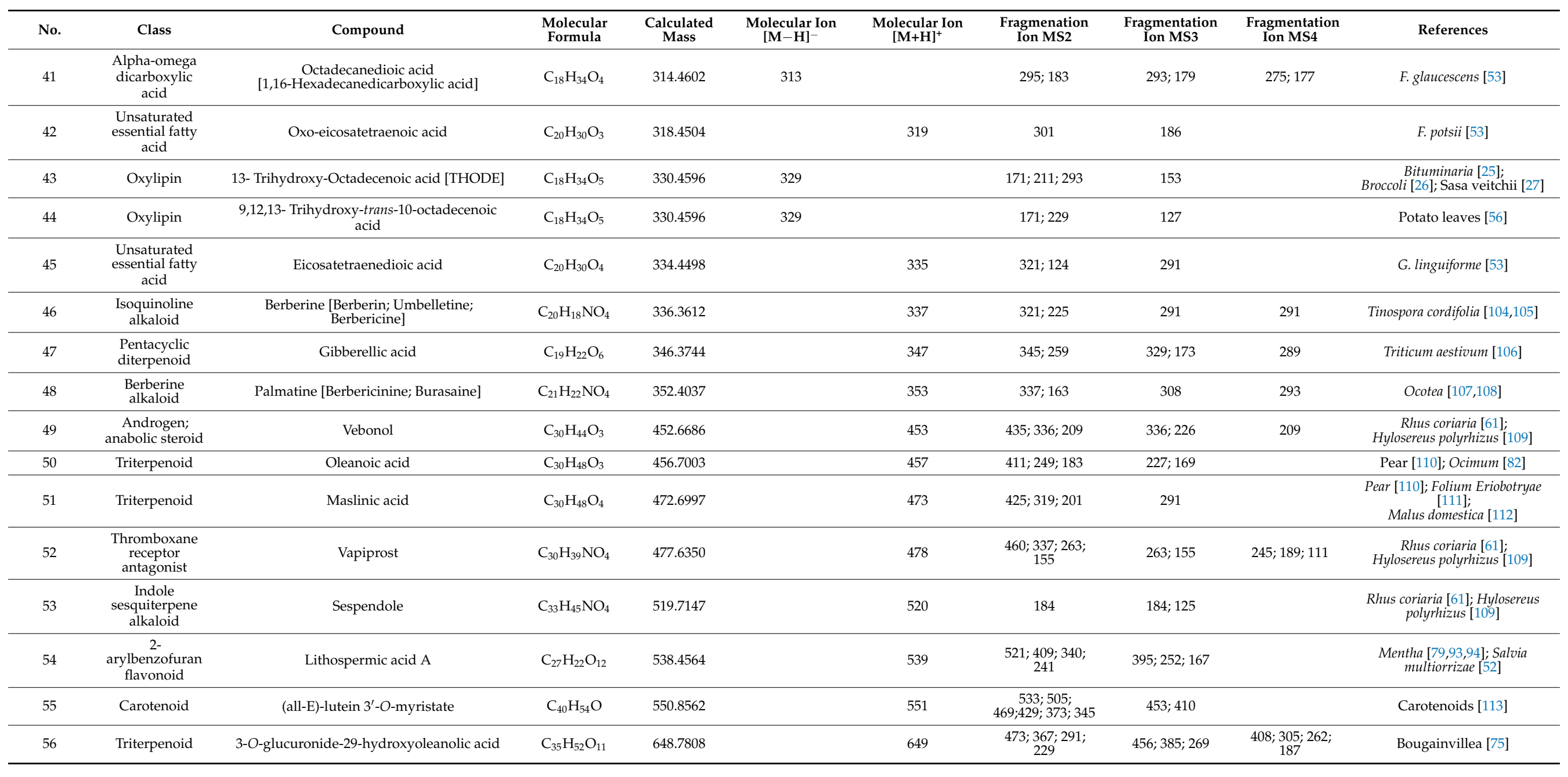




\section{References}

1. Loy, D.; Lundy, E. Nutritional properties and feeding value of corn and its coproducts. In Corn; Elsevier: Amsterdam, The Netherlands, 2019; pp. 633-659.

2. Salinas-Moreno, Y.; García-Salinas, C.; Ramírez-Díaz, J.L.; Alemán-de la Torre, I. Phenolic compounds in maize grains and its nixtamalized products. In Phenolic Compounds-Natural Sources, Importance and Applications, 1st ed.; Soto-Hernandez, M., Palma-Tenango, M., Garcia-Mateos, M.R., Eds.; InTech: Rijeka, Croatia, 2017; Chapter 8; pp. 215-232.

3. Adom, K.K.; Liu, R.H. Antioxidant activity of grains. J. Agric. Food Chem. 2002, 50, 6182-6187. [CrossRef] [PubMed]

4. Pigeolet, E.; Corbisier, P.; Houbion, A.; Lambert, D.; Michiels, C.; Raes, M.; Zachary, M.-D.; Remacle, J. Glutathione peroxidase, superoxide dismutase, and catalase inactivation by peroxides and oxygen derived free radicals. Mech. Ageing Dev. 1990, 51, 283-297. [CrossRef]

5. Dembinska-Kiec, A.; Mykkänen, O.; Kiec-Wilk, B.; Mykkänen, H. Antioxidant phytochemicals against type 2 diabetes. Br. J. Nutr. 2008, 99, ES109-ES117. [CrossRef] [PubMed]

6. Heim, K.E.; Tagliaferro, A.R.; Bobilya, D.J. Flavonoid antioxidants: Chemistry, metabolism and structure-activity relationships. J. Nutr. Biochem. 2002, 13, 572-584. [CrossRef]

7. Nijveldt, R.J.; Van Nood, E.; Van Hoorn, D.E.; Boelens, P.G.; Van Norren, K.; Van Leeuwen, P.A. Flavonoids: A review of probable mechanisms of action and potential applications. Am. J. Clin. Nutr. 2001, 74, 418-425. [CrossRef]

8. Zheng, Y.-Z.; Deng, G.; Guo, R.; Fu, Z.-M.; Chen, D.-F. The influence of the H5 * OC4 intramolecular hydrogen-bond (IHB) on the antioxidative activity of flavonoid. Phytochemistry 2019, 160, 19-24. [CrossRef]

9. Terao, J. Factors modulating bioavailability of quercetin-related flavonoids and the consequences of their vascular function. Biochem. Pharmacol. 2017, 139, 15-23. [CrossRef]

10. Győri, Z. Corn: Grain-Quality Characteristics and Management of Quality Requirements. In Cereal Grains; Elsevier: Amsterdam, The Netherlands, 2017; pp. 257-290.

11. Szwajgier, D. Anticholinesterase activity of selected phenolic acids and flavonoids-interaction testing in model solutions. Ann. Agric. Environ. Med. 2015, 22, 690-694. [CrossRef]

12. Weber, E.J. Carotenoids and tocols of corn grain determined by HPLC. J. Am. Oil Chem. Soc. 1987, 64, 1129-1134. [CrossRef]

13. Kljak, K.; Grbeša, D. Carotenoid content and antioxidant activity of hexane extracts from selected Croatian corn hybrids. Food Chem. 2015, 167, 402-408. [CrossRef]

14. Ndolo, V.U.; Beta, T. Distribution of carotenoids in endosperm, germ, and aleurone fractions of cereal grain kernels. Food Chem. 2013, 139, 663-671. [CrossRef] [PubMed]

15. Li, Q.; Somavat, P.; Singh, V.; Chatham, L.; de Mejia, E.G. A comparative study of anthocyanin distribution in purple and blue corn coproducts from three conventional fractionation processes. Food Chem. 2017, 231, 332-339. [CrossRef] [PubMed]

16. Farrés-Cebrián, M.; Seró, R.; Saurina, J.; Núñez, O. HPLC-UV polyphenolic profiles in the classification of olive oils and other vegetable oils via principal component analysis. Separations 2016, 3, 33. [CrossRef]

17. Gálvez Ranilla, L. The application of metabolomics for the study of cereal corn (Zea mays L.). Metabolites 2020, 10, 300. [CrossRef] [PubMed]

18. Peniche-Pavía, H.A.; Tiessen, A. Anthocyanin profiling of maize grains using DIESI-MSQD reveals that cyanidin-based derivatives predominate in purple corn, whereas pelargonidin-based molecules occur in red-pink varieties from Mexico. J. Agric. Food Chem. 2020, 68, 5980-5994. [CrossRef]

19. Cuevas Montilla, E.; Hillebrand, S.; Antezana, A.; Winterhalter, P. Soluble and bound phenolic compounds in different Bolivian purple corn (Zea mays L.) cultivars. J. Agric. Food Chem. 2011, 59, 7068-7074. [CrossRef]

20. Das, A.K.; Singh, V. Antioxidative free and bound phenolic constituents in botanical fractions of Indian specialty maize (Zea mays L.) genotypes. Food Chem. 2016, 201, 298-306. [CrossRef]

21. Meijering, E. Cell segmentation: 50 years down the road [life sciences]. IEEE Signal Processing Mag. 2012, 29, 140-145. [CrossRef]

22. Hutzler, P.; Fischbach, R.; Heller, W.; Jungblut, T.P.; Reuber, S.; Schmitz, R.; Veit, M.; Weissenböck, G.; Schnitzler, J.-P. Tissue localization of phenolic compounds in plants by confocal laser scanning microscopy. J. Exp. Bot. 1998, 49, 953-965. [CrossRef]

23. Jones, A.M.P.; Shukla, M.R.; Chattopadhyay, A.; Zoń, J.; Saxena, P.K. Investigating the roles of phenylpropanoids in the growth and development of Zea mays L. Vitr. Cell. Dev. Biol. -Plant 2013, 49, 765-772. [CrossRef]

24. Luna-Vital, D.A.; Chatham, L.; Juvik, J.; Singh, V.; Somavat, P.; De Mejia, E.G. Activating effects of phenolics from Apache Red Zea mays L. on free fatty acid receptor 1 and glucokinase evaluated with a dual culture system with epithelial, pancreatic, and liver cells. J. Agric. Food Chem. 2019, 67, 9148-9159. [CrossRef] [PubMed]

25. Llorent-Martínez, E.J.; Spínola, V.; Gouveia, S.; Castilho, P.C. HPLC-ESI-MSn characterization of phenolic compounds, terpenoid saponins, and other minor compounds in Bituminaria bituminosa. Ind. Crops Prod. 2015, 69, 80-90. [CrossRef]

26. Park, S.K.; Ha, J.S.; Kim, J.M.; Kang, J.Y.; Lee, D.S.; Guo, T.J.; Lee, U.; Kim, D.-O.; Heo, H.J. Antiamnesic effect of broccoli (Brassica oleracea var. italica) leaves on amyloid beta (A $\beta$ ) 1-42-induced learning and memory impairment. J. Agric. Food Chem. 2016, 64, 3353-3361. [CrossRef] [PubMed]

27. Van Hoyweghen, L.; De Bosscher, K.; Haegeman, G.; Deforce, D.; Heyerick, A. In vitro inhibition of the transcription factor NF- $k B$ and cyclooxygenase by Bamboo extracts. Phytother. Res. 2014, 28, 224-230. [CrossRef] 
28. Dinelli, G.; Segura-Carretero, A.; Di Silvestro, R.; Marotti, I.; Arráez-Román, D.; Benedettelli, S.; Ghiselli, L.; Fernadez-Gutierrez, A. Profiles of phenolic compounds in modern and old common wheat varieties determined by liquid chromatography coupled with time-of-flight mass spectrometry. J. Chromatogr. A 2011, 1218, 7670-7681. [CrossRef]

29. Garg, M.; Chawla, M.; Chunduri, V.; Kumar, R.; Sharma, S.; Sharma, N.K.; Kaur, N.; Kumar, A.; Mundey, J.K.; Saini, M.K. Transfer of grain colors to elite wheat cultivars and their characterization. J. Cereal Sci. 2016, 71, 138-144. [CrossRef]

30. Sun, J.; Liu, X.; Yang, T.; Slovin, J.; Chen, P. Profiling polyphenols of two diploid strawberry (Fragaria vesca) inbred lines using UHPLC-HRMSn. Food Chem. 2014, 146, 289-298. [CrossRef]

31. Corcel, M.; Devaux, M.-F.; Guillon, F.; Barron, C. Identification of tissular origin of particles based on autofluorescence multispectral image analysis at the macroscopic scale. In Proceedings of the EPJ Web of Conferences, Crete, Greece, 17-29 August 2017; p. 05012.

32. Lichtenthaler, H.K.; Schweiger, J. Cell wall bound ferulic acid, the major substance of the blue-green fluorescence emission of plants. J. Plant Physiol. 1998, 152, 272-282. [CrossRef]

33. Rudall, P.; Caddick, L. Investigation of the presence of phenolic compounds in monocotyledonous cell walls, using UV fluorescence microscopy. Ann. Bot. 1994, 74, 483-491. [CrossRef]

34. Philippe, S.; Tranquet, O.; Utille, J.-P.; Saulnier, L.; Guillon, F. Investigation of ferulate deposition in endosperm cell walls of mature and developing wheat grains by using a polyclonal antibody. Planta 2007, 225, 1287-1299. [CrossRef]

35. Das, A.K.; Singh, V. Antioxidative free and bound phenolic constituents in pericarp, germ and endosperm of Indian dent (Zea mays var. indentata) and flint (Zea mays var. indurata) maize. J. Funct. Foods 2015, 13, 363-374. [CrossRef]

36. Antoine, C.; Peyron, S.; Mabille, F.; Lapierre, C.; Bouchet, B.; Abecassis, J.; Rouau, X. Individual contribution of grain outer layers and their cell wall structure to the mechanical properties of wheat bran. J. Agric. Food Chem. 2003, 51, 2026-2033. [CrossRef] [PubMed]

37. Hernanz, D.; Nuñez, V.; Sancho, A.I.; Faulds, C.B.; Williamson, G.; Bartolomé, B.; Gómez-Cordovés, C. Hydroxycinnamic acids and ferulic acid dehydrodimers in barley and processed barley. J. Agric. Food Chem. 2001, 49, 4884-4888. [CrossRef] [PubMed]

38. Rhodes, D.; Sadek, M.; Stone, B. Hydroxycinnamic acids in walls of wheat aleurone cells. J. Cereal Sci. 2002, 36, 67-81. [CrossRef]

39. Vanholme, R.; De Meester, B.; Ralph, J.; Boerjan, W. Lignin biosynthesis and its integration into metabolism. Curr. Opin. Biotechnol. 2019, 56, 230-239. [CrossRef]

40. Talamond, P.; Verdeil, J.-L.; Conéjéro, G. Secondary metabolite localization by autofluorescence in living plant cells. Molecules 2015, 20, 5024-5037. [CrossRef]

41. Tian, S.; Sun, Y.; Chen, Z.; Yang, Y.; Wang, Y. Functional properties of polyphenols in grains and effects of physicochemical processing on polyphenols. J. Food Qual. 2019, 2019, 2793973. [CrossRef]

42. Fulcher, R.; O'Brien, T.; Lee, J. Conventional and fluorescence microcopy of the cell wall with emphasis on phenol-carbohydrate complexes in wheat. Aust. J. Biol. Sci. 1972, 25, 23-34. [CrossRef]

43. Holopainen, U.R.; Wilhelmson, A.; Salmenkallio-Marttila, M.; Peltonen-Sainio, P.; Rajala, A.; Reinikainen, P.; Kotaviita, E.; Simolin, H.; Home, S. Endosperm structure affects the malting quality of barley (Hordeum vulgare L.). J. Agric. Food Chem. 2005, 53, 7279-7287. [CrossRef]

44. Jääskeläinen, A.-S.; Holopainen-Mantila, U.; Tamminen, T.; Vuorinen, T. Endosperm and aleurone cell structure in barley and wheat as studied by optical and Raman microscopy. J. Cereal Sci. 2013, 57, 543-550. [CrossRef]

45. Saadi, A.; Lempereur, I.; Sharonov, S.; Autran, J.; Manfait, M. Spatial distribution of phenolic materials in durum wheat grain as probed by confocal fluorescence spectral imaging. J. Cereal Sci. 1998, 28, 107-114. [CrossRef]

46. Piot, O.; Autran, J.-C.; Manfait, M. Spatial distribution of protein and phenolic constituents in wheat grain as probed by confocal Raman microspectroscopy. J. Cereal Sci. 2000, 32, 57-71. [CrossRef]

47. Azmir, J.; Zaidul, I.S.M.; Rahman, M.M.; Sharif, K.; Mohamed, A.; Sahena, F.; Jahurul, M.; Ghafoor, K.; Norulaini, N.; Omar, A. Techniques for extraction of bioactive compounds from plant materials: A review. J. Food Eng. 2013, 117, 426-436. [CrossRef]

48. Zhang, A.; Wan, L.; Wu, C.; Fang, Y.; Han, G.; Li, H.; Zhang, Z.; Wang, H. Simultaneous determination of 14 phenolic compounds in grape canes by HPLC-DAD-UV using wavelength switching detection. Molecules 2013, 18, 14241-14257. [CrossRef]

49. Olennikov, D.N.; Chirikova, N.K.; Okhlopkova, Z.M.; Zulfugarov, I.S. Chemical composition and antioxidant activity of Tánara Ótó (Dracocephalum palmatum Stephan), a medicinal plant used by the North-Yakutian nomads. Molecules 2013, 18, 14105-14121. [CrossRef]

50. Santos, S.n.A.; Freire, C.S.; Domingues, M.R.M.; Silvestre, A.J.; Neto, C.P. Characterization of phenolic components in polar extracts of Eucalyptus globulus Labill. bark by high-performance liquid chromatography-mass spectrometry. J. Agric. Food Chem. 2011, 59, 9386-9393. [CrossRef]

51. Sharma, M.; Sandhir, R.; Singh, A.; Kumar, P.; Mishra, A.; Jachak, S.; Singh, S.P.; Singh, J.; Roy, J. Comparative analysis of phenolic compound characterization and their biosynthesis genes between two diverse bread wheat (Triticum aestivum) varieties differing for chapatti (unleavened flat bread) quality. Front. Plant Sci. 2016, 7, 1870. [CrossRef]

52. Jiang, R.-W.; Lau, K.-M.; Hon, P.-M.; Mak, T.C.; Woo, K.-S.; Fung, K.-P. Chemistry and biological activities of caffeic acid derivatives from Salvia miltiorrhiza. Curr. Med. Chem. 2005, 12, 237-246. [CrossRef]

53. Hamed, A.R.; El-Hawary, S.S.; Ibrahim, R.M.; Abdelmohsen, U.R.; El-Halawany, A.M. Identification of Chemopreventive Components from Halophytes Belonging to Aizoaceae and Cactaceae Through LC/MS—Bioassay Guided Approach. J. Chromatogr. Sci. 2021, 59, 618-626. [CrossRef] 
54. Aita, S.E.; Capriotti, A.L.; Cavaliere, C.; Cerrato, A.; Giannelli Moneta, B.; Montone, C.M.; Piovesana, S.; Laganà, A. Andean Blueberry of the Genus Disterigma: A High-Resolution Mass Spectrometric Approach for the Comprehensive Characterization of Phenolic Compounds. Separations 2021, 8, 58. [CrossRef]

55. Zhu, Z.-W.; Li, J.; Gao, X.-M.; Amponsem, E.; Kang, L.-Y.; Hu, L.-M.; Zhang, B.-L.; Chang, Y.-X. Simultaneous determination of stilbenes, phenolic acids, flavonoids and anthraquinones in Radix polygoni multiflori by LC-MS/MS. J. Pharm. Biomed. Anal. 2012, 62, 162-166. [CrossRef]

56. Rodríguez-Pérez, C.; Gómez-Caravaca, A.M.; Guerra-Hernández, E.; Cerretani, L.; García-Villanova, B.; Verardo, V. Comprehensive metabolite profiling of Solanum tuberosum L.(potato) leaves by HPLC-ESI-QTOF-MS. Food Res. Int. 2018, 112, 390-399. [CrossRef] [PubMed]

57. Stallmann, J.; Schweiger, R.; Pons, C.A.; Müller, C. Wheat growth, applied water use efficiency and flag leaf metabolome under continuous and pulsed deficit irrigation. Sci. Rep. 2020, 10, 1-13. [CrossRef] [PubMed]

58. Fuentes, J.A.M.; López-Salas, L.; Borrás-Linares, I.; Navarro-Alarcón, M.; Segura-Carretero, A.; Lozano-Sánchez, J. Development of an innovative pressurized liquid extraction procedure by response surface methodology to recover bioactive compounds from carao Tree Seeds. Foods 2021, 10, 398. [CrossRef]

59. Sobeh, M.; Mahmoud, M.F.; Abdelfattah, M.A.; Cheng, H.; El-Shazly, A.M.; Wink, M. A proanthocyanidin-rich extract from Cassia abbreviata exhibits antioxidant and hepatoprotective activities in vivo. J. Ethnopharmacol. 2018, 213, 38-47. [CrossRef] [PubMed]

60. Thomford, N.E.; Dzobo, K.; Chopera, D.; Wonkam, A.; Maroyi, A.; Blackhurst, D.; Dandara, C. In vitro reversible and timedependent CYP450 inhibition profiles of medicinal herbal plant extracts Newbouldia laevis and Cassia abbreviata: Implications for herb-drug interactions. Molecules 2016, 21, 891. [CrossRef] [PubMed]

61. Abu-Reidah, I.M.; Ali-Shtayeh, M.S.; Jamous, R.M.; Arráez-Román, D.; Segura-Carretero, A. HPLC-DAD-ESI-MS/MS screening of bioactive components from Rhus coriaria L.(Sumac) fruits. Food Chem. 2015, 166, 179-191. [CrossRef] [PubMed]

62. Cai, Z.; Wang, C.; Zou, L.; Liu, X.; Chen, J.; Tan, M.; Mei, Y.; Wei, L. Comparison of multiple bioactive constituents in the flower and the caulis of Lonicera japonica based on UFLC-QTRAP-MS/MS combined with multivariate statistical analysis. Molecules 2019, 24, 1936. [CrossRef] [PubMed]

63. Oertel, A.; Matros, A.; Hartmann, A.; Arapitsas, P.; Dehmer, K.J.; Martens, S.; Mock, H.-P. Metabolite profiling of red and blue potatoes revealed cultivar and tissue specific patterns for anthocyanins and other polyphenols. Planta 2017, 246, 281-297. [CrossRef]

64. Deußer, H.; Guignard, C.; Hoffmann, L.; Evers, D. Polyphenol and glycoalkaloid contents in potato cultivars grown in Luxembourg. Food Chem. 2012, 135, 2814-2824. [CrossRef]

65. Chandrasekara, A.; Shahidi, F. Determination of antioxidant activity in free and hydrolyzed fractions of millet grains and characterization of their phenolic profiles by HPLC-DAD-ESI-MSn. J. Funct. Foods 2011, 3, 144-158. [CrossRef]

66. Yasir, M.; Sultana, B.; Anwar, F. LC-ESI-MS/MS based characterization of phenolic components in fruits of two species of Solanaceae. J. Food Sci. Technol. 2018, 55, 2370-2376. [CrossRef] [PubMed]

67. Quifer-Rada, P.; Vallverdú-Queralt, A.; Martínez-Huélamo, M.; Chiva-Blanch, G.; Jáuregui, O.; Estruch, R.; Lamuela-Raventós, R. A comprehensive characterisation of beer polyphenols by high resolution mass spectrometry (LC-ESI-LTQ-Orbitrap-MS). Food Chem. 2015, 169, 336-343. [CrossRef]

68. Ojwang, L.O.; Yang, L.; Dykes, L.; Awika, J. Proanthocyanidin profile of cowpea (Vigna unguiculata) reveals catechin-O-glucoside as the dominant compound. Food Chem. 2013, 139, 35-43. [CrossRef]

69. Sobeh, M.; Mahmoud, M.F.; Hasan, R.A.; Cheng, H.; El-Shazly, A.M.; Wink, M. Senna singueana: Antioxidant, hepatoprotective, antiapoptotic properties and phytochemical profiling of a methanol bark extract. Molecules 2017, 22, 1502. [CrossRef]

70. Qin, D.; Wang, Q.; Li, H.; Jiang, X.; Fang, K.; Wang, Q.; Li, B.; Pan, C.; Wu, H. Identification of key metabolites based on non-targeted metabolomics and chemometrics analyses provides insights into bitterness in Kucha [Camellia kucha (Chang et Wang) Chang]. Food Res. Int. 2020, 138, 109789. [CrossRef] [PubMed]

71. Spínola, V.; Pinto, J.; Castilho, P.C. Identification and quantification of phenolic compounds of selected fruits from Madeira Island by HPLC-DAD-ESI-MSn and screening for their antioxidant activity. Food Chem. 2015, 173, 14-30. [CrossRef]

72. Chang, Q.; Wong, Y.-S. Identification of flavonoids in Hakmeitau beans (Vigna sinensis) by high-performance liquid chromatography - electrospray mass spectrometry (LC-ESI/MS). J. Agric. Food Chem. 2004, 52, 6694-6699. [CrossRef]

73. Vieira, M.N.; Winterhalter, P.; Jerz, G. Flavonoids from the flowers of Impatiens glandulifera Royle isolated by high performance countercurrent chromatography. Phytochem. Anal. 2016, 27, 116-125. [CrossRef]

74. Vallverdú-Queralt, A.; Jáuregui, O.; Medina-Remón, A.; Lamuela-Raventós, R.M. Evaluation of a method to characterize the phenolic profile of organic and conventional tomatoes. J. Agric. Food Chem. 2012, 60, 3373-3380. [CrossRef]

75. El-sayed, M.; Abbas, F.A.; Refaat, S.; El-Shafae, A.M.; Fikry, E. UPLC-ESI-MS/MS Profile of The Ethyl Acetate Fraction of Aerial Parts of Bougainvillea'Scarlett O'Hara'Cultivated in Egypt. Egypt. J. Chem. 2021, 64, 6-7.

76. De Freitas, M.A.; Silva Alves, A.I.; Andrade, J.C.; Leite-Andrade, M.C.; Lucas dos Santos, A.T.; Felix de Oliveira, T.; dos Santos, F.d.A.G.; Silva Buonafina, M.D.; Melo Coutinho, H.D.; Alencar de Menezes, I.R. Evaluation of the antifungal activity of the Licania rigida leaf ethanolic extract against biofilms formed by Candida sp. isolates in acrylic resin discs. Antibiotics $2019,8,250$. [CrossRef] [PubMed]

77. Bujor, O.-C. Extraction, Identification and Antioxidant Activity of the Phenolic Secondary Metabolites Isolated from the Leaves, Stems and Fruits of Two Shrubs of the Ericaceae Family; Universite d'Avignon: Avignon, France, 2016. 
78. Zhou, X.-J.; Yan, L.-L.; Yin, P.-P.; Shi, L.-L.; Zhang, J.-H.; Liu, Y.-J.; Ma, C. Structural characterisation and antioxidant activity evaluation of phenolic compounds from cold-pressed Perilla frutescens var. arguta seed flour. Food Chem. 2014, 164, $150-157$. [CrossRef] [PubMed]

79. Chen, X.; Zhang, S.; Xuan, Z.; Ge, D.; Chen, X.; Zhang, J.; Wang, Q.; Wu, Y.; Liu, B. The phenolic fraction of Mentha Haplocalyx and its constituent linarin ameliorate inflammatory response through inactivation of NF- $\mathrm{B}$ and MAPKs in lipopolysaccharideinduced RAW264. 7 cells. Molecules 2017, 22, 811. [CrossRef] [PubMed]

80. Paudel, L.; Wyzgoski, F.J.; Scheerens, J.C.; Chanon, A.M.; Reese, R.N.; Smiljanic, D.; Wesdemiotis, C.; Blakeslee, J.J.; Riedl, K.M.; Rinaldi, P.L. Nonanthocyanin secondary metabolites of black raspberry (Rubus occidentalis L.) fruits: Identification by HPLC-DAD, NMR, HPLC-ESI-MS, and ESI-MS/MS analyses. J. Agric. Food Chem. 2013, 61, 12032-12043. [CrossRef]

81. Kim, S.; Oh, S.; Noh, H.B.; Ji, S.; Lee, S.H.; Koo, J.M.; Choi, C.W.; Jhun, H.P. In vitro antioxidant and anti-propionibacterium acnes activities of cold water, hot water, and methanol extracts, and their respective ethyl acetate fractions, from Sanguisorba officinalis L. Roots. Molecules 2018, 23, 3001. [CrossRef]

82. Pandey, R.; Kumar, B. HPLC-QTOF-MS/MS-based rapid screening of phenolics and triterpenic acids in leaf extracts of Ocimum species and their interspecies variation. J. Liq. Chromatogr. Relat. Technol. 2016, 39, 225-238. [CrossRef]

83. Prasad Pandey, B.; Prakash Pradhan, S.; Adhikari, K. LC-ESI-QTOF-MS for the Profiling of the Metabolites and in Vitro Enzymes Inhibition Activity of Bryophyllum pinnatum and Oxalis corniculata Collected from Ramechhap District of Nepal. Chem. Biodivers. 2020, 17, e2000155. [CrossRef]

84. Enerstvedt, K.H.; Jordheim, M.; Andersen, Ø.M. Isolation and identification of flavonoids found in Zostera marina collected in Norwegian coastal waters. Am. J. Plant Sci. 2016, 7, 1163-1172. [CrossRef]

85. Teles, Y.C.; Horta, C.C.R.; Agra, M.D.F.; Siheri, W.; Boyd, M.; Igoli, J.O.; Gray, A.I.; De Souza, M.D.F.V. New sulphated flavonoids from Wissadula periplocifolia (L.) C. Presl (Malvaceae). Molecules 2015, 20, 20161-20172. [CrossRef]

86. Bonzanini, F.; Bruni, R.; Palla, G.; Serlataite, N.; Caligiani, A. Identification and distribution of lignans in Punica granatum L. fruit endocarp, pulp, seeds, wood knots and commercial juices by GC-MS. Food Chem. 2009, 117, 745-749. [CrossRef]

87. Čukelj, N.; Jakasa, I.; Sarajlija, H.; Novotni, D.; Ćurić, D. Identification and quantification of lignans in wheat bran by gas chromatography-electron capture detection. Talanta 2011, 84, 127-132. [CrossRef] [PubMed]

88. Eklund, P.C.; Backman, M.J.; Kronberg, L.Å.; Smeds, A.I.; Sjöholm, R.E. Identification of lignans by liquid chromatographyelectrospray ionization ion-trap mass spectrometry. J. Mass Spectrom. 2008, 43, 97-107. [CrossRef]

89. Cavaliere, C.; Foglia, P.; Pastorini, E.; Samperi, R.; Laganà, A. Identification and mass spectrometric characterization of glycosylated flavonoids in Triticum durum plants by high-performance liquid chromatography with tandem mass spectrometry. Rapid Commun. Mass Spectrom. Int. J. Devoted Rapid Dissem. Minute Res. Mass Spectrom. 2005, 19, 3143-3158. [CrossRef] [PubMed]

90. De Rosso, V.V.; Hillebrand, S.; Montilla, E.C.; Bobbio, F.O.; Winterhalter, P.; Mercadante, A.Z. Determination of anthocyanins from acerola (Malpighia emarginata DC.) and açai (Euterpe oleracea Mart.) by HPLC-PDA-MS/MS. J. Food Compos. Anal. 2008, 21, 291-299. [CrossRef]

91. Chen, W.; Gong, L.; Guo, Z.; Wang, W.; Zhang, H.; Liu, X.; Yu, S.; Xiong, L.; Luo, J. A novel integrated method for large-scale detection, identification, and quantification of widely targeted metabolites: Application in the study of rice metabolomics. Mol. Plant 2013, 6, 1769-1780. [CrossRef]

92. Yin, N.-W.; Wang, S.-X.; Jia, L.-D.; Zhu, M.-C.; Yang, J.; Zhou, B.-J.; Yin, J.-M.; Lu, K.; Wang, R.; Li, J.-N. Identification and characterization of major constituents in different-colored rapeseed petals by UPLC-HESI-MS/MS. J. Agric. Food Chem. 2019, 67, 11053-11065. [CrossRef]

93. Xu, L.-L.; Xu, J.-J.; Zhong, K.-R.; Shang, Z.-P.; Wang, F.; Wang, R.-F.; Zhang, L.; Zhang, J.-Y.; Liu, B. Analysis of non-volatile chemical constituents of Menthae Haplocalycis herba by ultra-high performance liquid chromatography-high resolution mass spectrometry. Molecules 2017, 22, 1756. [CrossRef]

94. Bodalska, A.; Kowalczyk, A.; Włodarczyk, M.; Fecka, I. Analysis of Polyphenolic Composition of a Herbal Medicinal ProductPeppermint Tincture. Molecules 2020, 25, 69. [CrossRef]

95. Shi, F.; Pan, H.; Lu, Y.; Ding, L. An HPLC-MS/MS method for the simultaneous determination of luteolin and its major metabolites in rat plasma and its application to a pharmacokinetic study. J. Sep. Sci. 2018, 41, 3830-3839. [CrossRef]

96. Geng, P.; Sun, J.; Zhang, M.; Li, X.; Harnly, J.M.; Chen, P. Comprehensive characterization of C-glycosyl flavones in wheat (Triticum aestivum L.) germ using UPLC-PDA-ESI/HRMSn and mass defect filtering. J. Mass Spectrom. 2016, 51, 914-930. [CrossRef] [PubMed]

97. Wojakowska, A.; Perkowski, J.; Góral, T.; Stobiecki, M. Structural characterization of flavonoid glycosides from leaves of wheat (Triticum aestivum L.) using LC/MS/MS profiling of the target compounds. J. Mass Spectrom. 2013, 48, 329-339. [CrossRef] [PubMed]

98. Mateos-Martín, M.L.; Fuguet, E.; Jiménez-Ardón, A.; Herrero-Uribe, L.; Tamayo-Castillo, G.; Torres, J.L. Identification of polyphenols from antiviral Chamaecrista nictitans extract using high-resolution LC-ESI-MS/MS. Anal. Bioanal. Chem. 2014, 406, 5501-5506. [CrossRef] [PubMed]

99. Ozarowski, M.; Piasecka, A.; Paszel-Jaworska, A.; Chaves, D.S.d.A.; Romaniuk, A.; Rybczynska, M.; Gryszczynska, A.; Sawikowska, A.; Kachlicki, P.; Mikolajczak, P.L. Comparison of bioactive compounds content in leaf extracts of Passiflora incarnata, P. caerulea and P. alata and in vitro cytotoxic potential on leukemia cell lines. Rev. Bras. Farmacogn. 2018, $28,179-191$. [CrossRef] 
100. Perchuk, I.; Shelenga, T.; Gurkina, M.; Miroshnichenko, E.; Burlyaeva, M. Composition of Primary and Secondary Metabolite Compounds in Seeds and Pods of Asparagus Bean (Vigna unguiculata (L.) Walp.) from China. Molecules 2020, 25, 3778. [CrossRef]

101. Rogachev, A.; Fomenko, V.; Sal'nikova, O.; Pokrovskii, L.; Salakhutdinov, N. Comparative analysis of essential oil compositions from leaves and stems of Rhododendron adamsii, $R$. aureum, and $R$. dauricum. Chem. Nat. Compd. 2006, 42, 426-430. [CrossRef]

102. Yang, S.; Wu, X.; Rui, W.; Guo, J.; Feng, Y. UPLC/Q-TOF-MS analysis for identification of hydrophilic phenolics and lipophilic diterpenoids from Radix Salviae Miltiorrhizae. Acta Chromatogr. 2015, 27, 711-728. [CrossRef]

103. Ekeberg, D.; Flæte, P.-O.; Eikenes, M.; Fongen, M.; Naess-Andresen, C.F. Qualitative and quantitative determination of extractives in heartwood of Scots pine (Pinus sylvestris L.) by gas chromatography. J. Chromatogr. A 2006, 1109, 267-272. [CrossRef]

104. Mittal, J.; Sharma, M.M. Enhanced production of berberine in In vitro regenerated cell of Tinospora cordifolia and its analysis through LCMS QToF. 3 Biotech 2017, 7, 25. [CrossRef]

105. Yan, X.; Zhao, Y.; Zhang, Y.; Qu, H. Monoclonal antibodies and immunoassay for medical plant-derived natural products: A review. Molecules 2017, 22, 355. [CrossRef]

106. Hou, S.; Zhu, J.; Ding, M.; Lv, G. Simultaneous determination of gibberellic acid, indole-3-acetic acid and abscisic acid in wheat extracts by solid-phase extraction and liquid chromatography-electrospray tandem mass spectrometry. Talanta 2008, 76, 798-802. [CrossRef] [PubMed]

107. Cassiano, D.S.A.; Reis, I.M.A.; de Oliveira Estrela, I.; de Freitas, H.F.; da Rocha Pita, S.S.; David, J.M.; Branco, A. Acetylcholinesterase inhibitory activities and bioguided fractionation of the Ocotea percoriacea extracts: HPLC-DAD-MS/MS characterization and molecular modeling of their alkaloids in the active fraction. Comput. Biol. Chem. 2019, 83, 107129. [CrossRef] [PubMed]

108. Yang, L.; Meng, X.; Yu, X.; Kuang, H. Simultaneous determination of anemoside B4, phellodendrine, berberine, palmatine, obakunone, esculin, esculetin in rat plasma by UPLC-ESI-MS/MS and its application to a comparative pharmacokinetic study in normal and ulcerative colitis rats. J. Pharm. Biomed. Anal. 2017, 134, 43-52. [CrossRef] [PubMed]

109. Wu, Y.; Xu, J.; He, Y.; Shi, M.; Han, X.; Li, W.; Zhang, X.; Wen, X. Metabolic profiling of pitaya (Hylocereus polyrhizus) during fruit development and maturation. Molecules 2019, 24, 1114. [CrossRef] [PubMed]

110. Sun, L.; Tao, S.; Zhang, S. Characterization and quantification of polyphenols and triterpenoids in thinned young fruits of ten pear varieties by UPLC-Q TRAP-MS/MS. Molecules 2019, 24, 159. [CrossRef]

111. Li, Z.H.; Zhu, H.; Cai, X.P.; He, D.D.; Hua, J.L.; Ju, J.M.; Lv, H.; Ma, L.; Li, W.L. Simultaneous determination of five triterpene acids in rat plasma by liquid chromatography-mass spectrometry and its application in pharmacokinetic study after oral administration of Folium Eriobotryae effective fraction. Biomed. Chromatogr. 2015, 29, 1791-1797. [CrossRef]

112. Sut, S.; Zengin, G.; Maggi, F.; Malagoli, M.; Dall'Acqua, S. Triterpene acid and phenolics from ancient apples of Friuli Venezia Giulia as nutraceutical ingredients: LC-MS study and in vitro activities. Molecules 2019, 24, 1109. [CrossRef]

113. Mercadante, A.Z.; Rodrigues, D.B.; Petry, F.C.; Mariutti, L.R.B. Carotenoid esters in foods-A review and practical directions on analysis and occurrence. Food Res. Int. 2017, 99, 830-850. [CrossRef] 